This dissertation has been microfilmed exactly as received

$69-12,536$

PATTON, James Lloyd, 1941CHROMOSOME EVOLUTION IN THE POCKET MOUSE, PEROGNATHUS GOLDMANI OSGOOD.

University of Arizona, Ph.D., 1969

Zoology

University Microfilms، Inc., Ann Arbor, Michigan 


\title{
CHROMOSOME EVOLUTION IN THE POCKET MOUSE, PEROGNATHUS GOLDMANI OSGOOD .
}

\author{
by \\ James Lloyd Patton
}

A Dissertation Submitted to the Faculty of the DEPARTMENT OF BIOLOGICAL SCIEINCES

In Partial Fulfillment of the Requirements

For the Degree of

DOCTOR OF PHILOSOPHY

WITH A MAJOR IN ZOOLOGY

In the Graduate College

THE UNIVERSITY OF ARIZONA

1969 


\section{STATEMENT BY AUTHOR}

This dissertation has been submitted in partial fulfiljment of requirements for an advanced degree at The Unj.versity of Arizona and is deposited in the University Iibrary to be made available to borrowers under rules of the Library.

Brief quotations from this dissertation are allow.. able without special permission, provided that accurate acknowledgment of source is made. Requests for permission for extended quotation from or reproduction of this manuscript in whole or in part may be granted by the head of the major department or the Dean of the Graduate Coliege when in his juagment the proposed use of the materlal is in the intexests of scholarship. In all other instances, however, permission must be obtained from the author.

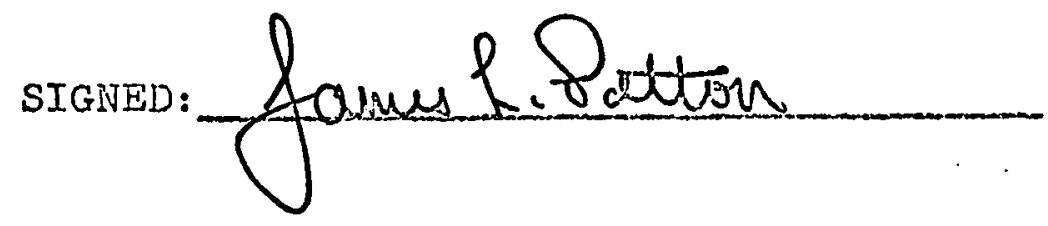




\section{ACKNOWLEDGMENTS}

Deepest gratitude is extended to Dr. W1lliam B. Heed under whose guidance this study was initlated and completed. Appreciation is also gratefully given to Drs. Charles H. Lowe, Wayne R. Ferris, Everett H. Lindsay, and Donaid L. Bryant for critically evaluating the manuscript. Special acknowledgment is due Drs. Oscar H. Soule and John W. Wright for ald in the field and for sound biological advice. The field ald of Messrs. Robert L. Bezy, Eldon J. Braun, Charles J. Cole, Alfred L. Gardner, G. Clay Mitchell, and Michael D. Robinson is also appreciated. Dr. Richard S. Felger aided in the identification of plants. 
TABLE OF CONTENTS

Page

LIST OF ILLUSTRATIONS . . . . . . . . . . . vi

LIST OF TABLES . . . . . . . . . . . . v vil

ABSTRACT . . . . . . . . . . . . . . vili

INTRODUCTION . . . . . . . . . . . . . 1

METHODS AND MATERIALS .............. 3

RACIAI CHARACTERISTICS . . . . . . . . . 5

Peropinothus goldmani- $-\alpha$. . . . . . . . $\quad 5$

Diagnosis

Geographic aistribution: : : : : 8

Ecological distribution ........ 8

Perognathus goldmani- $\beta$.......... 12

Karyotypic description :. . . . . . 12

Diagnosis . . . . . . . . . 14

Geographic distribution......... 14

Ecological distribution......... 14

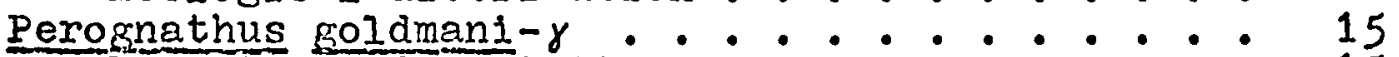

Karyotypic description . . . . . . . . 15

Diagnosis . . . . . . . . . . : 17

Geographic distribution ......: : 17

Ecological distribution.......... 17

Perognathus goldmani- $\delta$. . . . . . . . 18

Karyotypic description ......... 18

Diagnosis . . . .......... 18

Geographic distribution ......... 20

Ecological distribution......... 20

Perognathus goldmani- $\epsilon$. . . . . . . . . 21

Karyotypic description .......... 21

Djagnosis . . . . . . . . . 21

Geographic distribtuion .......... 21

Ecological distribution ......... 23

Perognathus goldmani- $\theta$........... 23

Karyotypic description ........ 23 
TABLE OF CONTENTS--Continued

Page

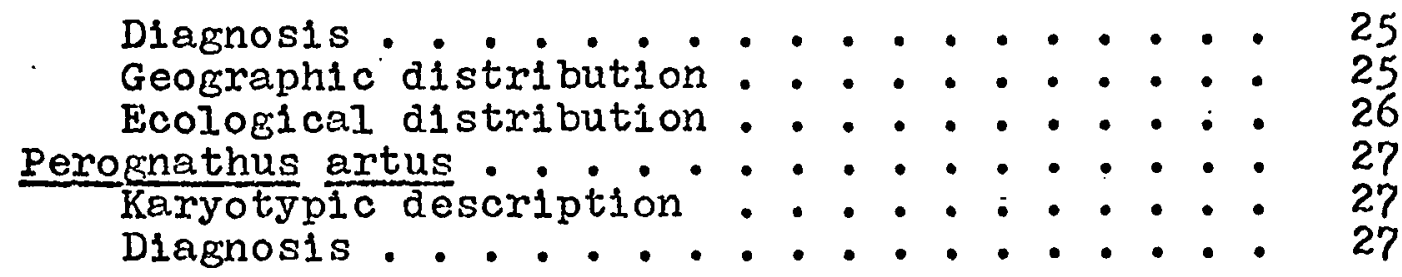

CHROMOSOME PHYLOGENY • . . . . . . . . . . . . 29 DISTRIBUTION PATTERNS . . . . . . . . . . . . 34 ECOLOGY AND POPULATION DYNAMICS OF CONTACT ZONES • 36 MORPHOLOGICAI TREINDS . . . . . . . . . . . 42 DISCUSSION . . . . . . . . . . . . . . 48 SPECIMENS EXAMINED . . . . . . . . . . . . 61 LITERATURE CITED . . . . . . . . . . . . . . 64 


\section{LIST OF ILLUSTRATIONS}

Figure

1. Distribution of Perognathus goldmani in Sonora and Sinaloa, Mexico, indicating known range of each chromosome race (hatching). . . 6

2. Karyotype of Perognathus goldman1-race $\alpha$.. . . ?

3. Karyotype of Perognathus goldmani-race $\alpha$ and Perognathus coldmani-race $\delta$ hybrid. . . . 9

4. Map of the Rio Mayo and adjacent Rio Cuchi jaqui drainages in southexn Sonora, Mexico, detalling localities and sample sizes for three chromosome races of P. goldmani . . 10

5. Map of the Rio Fuerte drainage in southern Sonora and northern Sinaloa, Mexico, detalling localities and sample sizes for three chromosome races of $\underline{P}$. goldman1. . 11

6. Karyotype of Peropnathus goldmant-race $\beta$. . . 13

7. Karyotype of Perognathus goldnan1-race $\gamma$. . 16

8. Karyotype of Perognathus goldmanj-race $\delta$. . 19

9. Karyotype of Perognathus goloman1-race $\epsilon$. . . 22

10. Karyotype of Perognathus goldmani-race $\theta$. . . 24

11. Karyotype of Perognathus artus . . . . . . 28

12. Diagrammatic chromosome phylogeny of the six chromosome races of P. goldrnan1 . . . 32

13. D1agrammatic cross-section of the Hio Cuchijaqui and adjacent area at 12 miles east of Alamos, Sonora, Mexico . . . . . . 39

14. Allopatric interpretation for the origin of the chromosome races of P. goldman1 . . . 55 


\section{IIST OF TABLES}

Table

Page

1. Summary of morphological characteristics of contiguous populations of races $\gamma$ and $\alpha$ in the vicinity of Navojoa, Sonora, Mexico ................ 44

2. Summary of morphological characteristics of contiguous populations of races $\alpha$ and $\delta$ south of Alamos, Sonora, Mexico . . 45

3. Summary of morphological characteristics of contiguous populations of races $\alpha$, $\delta$, and $\beta$ in the vicinity of El Fuerte, Sinaloa, Mexico 


\section{ABSTRACT}

Six chromosome races are described for the pocket mouse, Perognathus goldmani osgood. The species inhabits a relatively restricted geographic range from northeastern Sonora, Mexico, south into noxthern Sinaloa, Mexico, within thornscrub and short-tree forest communities. Two lines of evolution from an hypothetical ancestral arrangement account for the chromosome variants. One lineage involved the formation of a single race via a pericentric inversion in a small autosome; the second involved the formation of five races through a series of four autosomal centric fusions and a pericentric inversion in the $x$-chromosome. There is a sequential relationship between the present geographic distribution and the phylogenetic position of the races, with the more ancestral at the northern and southern geographic margins and the more derived in the interlor of the species range. Races exhibit contiguous allopatry, as contact between adjacent races is established alone major rivers. No localities of sympatry between races are known, and only three individuals of hybrid origin between any two races have been found. Migration and presumably gene flow between adjacent races is apparently at a 
minimum. Physlographic factors (rivers) and ecological factors (riparian communities and the competitive sibling species, $\underline{P}$. artus Osgood) combine to form a barrier to dispersal. An allopatric intexpretation for racial formation and a sequence of historical migration patterns and ecological shifts are hypothesized. 


\section{INTRODUCTION}

Pocket mice of the heteromyid rodent genus Perognathus provide unusual promise for the demonstration or phyletic evolution based on comparative chromosome characteristics. Within the seventeen species examined in depth to date, alploid numbers are found to vary between 34 (‥ h1sp1dus) and 56 (ㅁ. amplus and P. Longimembris). and only two species are currently known to have indistinguishable karyotypes (Patton 1967a, b, unpublished data). Moreover, an extensive geographic survey of each species has revealed numerous cases of intraspecific chromosomal variation, including intrapopulation polymorphism ( $\underline{P}$. balley1) and monomorphic chromosome races (… peniclilatus, P. pexnix. P. goldmanl, and $\underline{P}$. amplus). Some of these latter races correspond to currently recognized subspecies, but others permit recognition of differentiation not previously assessed by more conventional systematic methods.

Perognathus goldman1 osgood, al though considered taxonomically monomorphic, is characterized by an assemblage of six allopatric chromosome variants. The species is prevalent in thornscrub and short-tree forest habitats from extreme northeastern Sonora in the Rio Yaqui drainage 
through the coastal plains of sonora into northern sinaloa, in northwestern Mexico. Ilttle knowledge is avallable concerning blological aspects of the species, and only a single report with depth has been published since its original description by osgood (1900). This repoxt (Anderson 1964) deals with the systematic status of the species

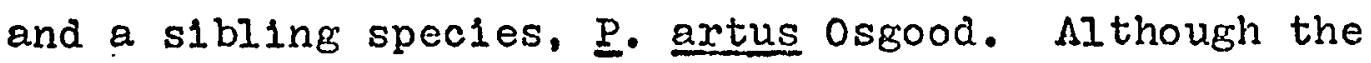
report concerns geographic variation, little information regarding population dymanics, ecology, and history is provided.

The present effort is an attempt to document the phylogenet1c characters and interpret historical relationships between the chromosome races of $\underline{P}$. goldmani, and also their relationship with $\underline{P}$. artus. This is done through an interpretation of the origin (historical influences) and mechanisms of chromosomal change, considering genet1c consequences, geographic distribution, and ecological relationships. The present study may clarify the adaptive significance of different chromosome combinations and their possible role in evolutionary divergence. 


\section{METHODS AND MATERIALS}

\section{A total of 319 specimens of p. Boldmen1 (177 males,}

142 females) from 47 localities within the Mexican states of Sonora and Sinaloa were trapped alive for the present analysis. All individuals were identified by the pelage and cranial cirteria of Anderson (1964). Conventional museum specimens of all animals have been prepared, and the majority are deposited in the collection of maramals, Department of Biological Sciences, The University of Arizona, Tucson. See list of specimens examined below for museun catalogue numbers and localities.

Metaphase chromosomes of dividing bone marrow cells were prepared using the in vivo colchicine-hypotonic citrate sequence described elsewhere (Patton 19679). Determination of diploid numbers, fundamental numbers, and chromosore morphology was made by standard analytical procedures (Bender and Chu 1963, Patton 1967a). An average of 15 cells vere examined per individual (a total of 4785 cells examined). Greater than 87.5 per cent of all cells belonged to the modal count chosen as the diploid number for each race. Karyotypes were prepared from photomicrographs. Autosomes are grouped Into morphological classes to facilitate comparison of the 
chromosome variants. These are: Group A, metacentrics and submetacentrics; Group B, "rabbit-ear" acrocentrics (terminolozy after Levan, Hsu, and Stich 1962); and Group C, acrocentrics. The sex chromosomes have been classified separately. Members of Group A are individually recognizable, and have been designated by subscripts indicative of their point of origin in the chromosome phylogeny. 


\section{RACIAL CHARACTERISTICS}

For present purposes, each chromosome race is designated by Greek letter. The order of the designations in no way indicates closeness of relationship, but merely the sequence in which each chromosomal variant was discovered. Only two localities are known from which intergrades between any two races have been found. No localities of sympatric contact between adjacent races are known. Each race is essentially monotypic, therefore, and can be defined chromosomally, ecologically, and geographically. The overall geographic distribution of the species and the six races is shown in Fig. 1.

\section{Perognathus goldman1- $\alpha$}

Karyotypic descrjption. A karyotype representative of this chromosome race has been presented elsewhere (Pattion 1967a). The diploid number is 52 and the fundamental number (FN) 54. According to the previously established nomenclature, the chromosomes can be arranged as follows (F1g. 2):

Group A: 2 palrs of medium submetacentrics (designated $A_{2}$ and $A_{4}$, respectively).

Group B: 1 pair of "rabbit-ear" acrocentrics. 


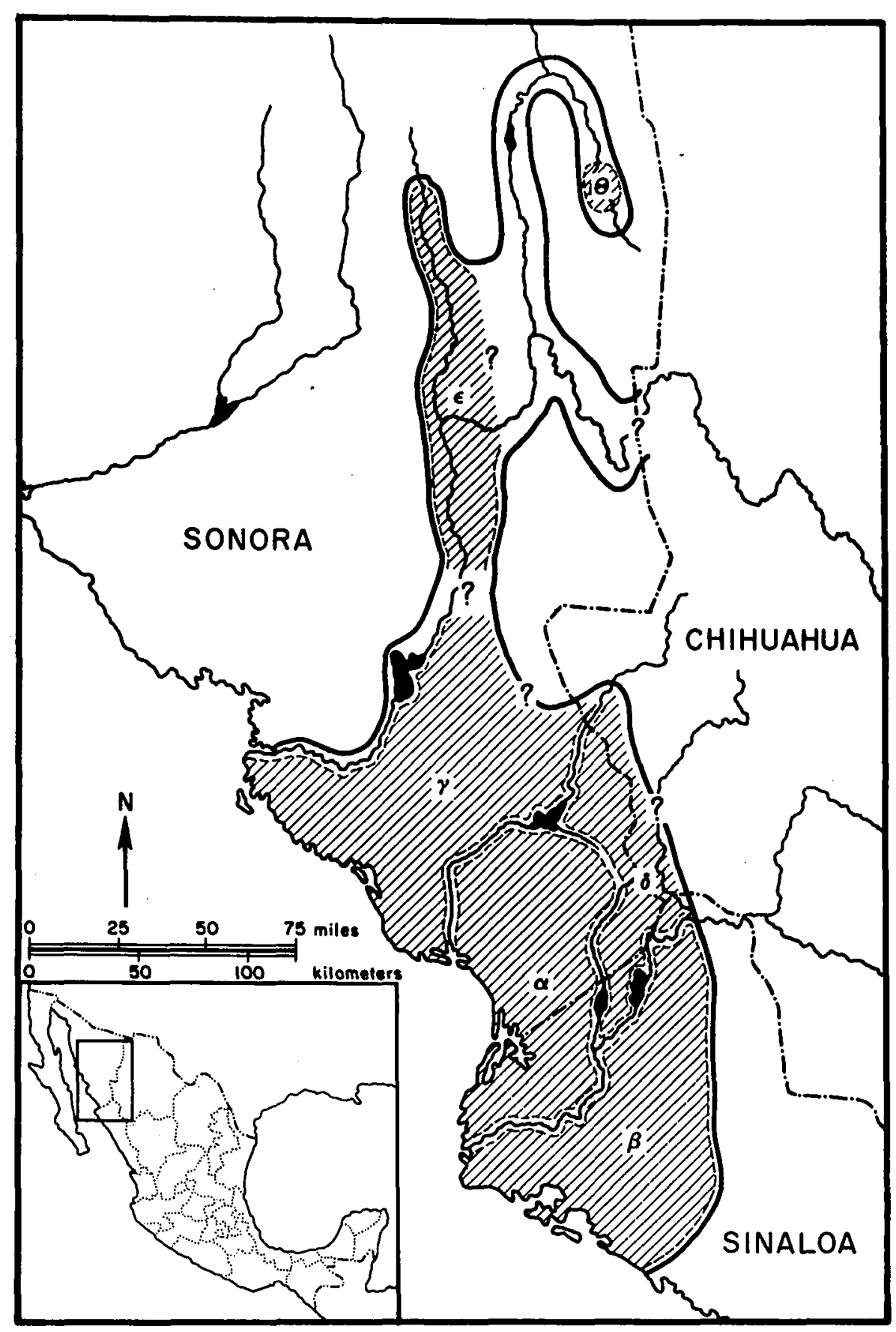

Fig. 1. Distribution of Perognathus goldmani in Sonora and sinaloa, Wexico, indicating known range of each chromosome race (hatching). 


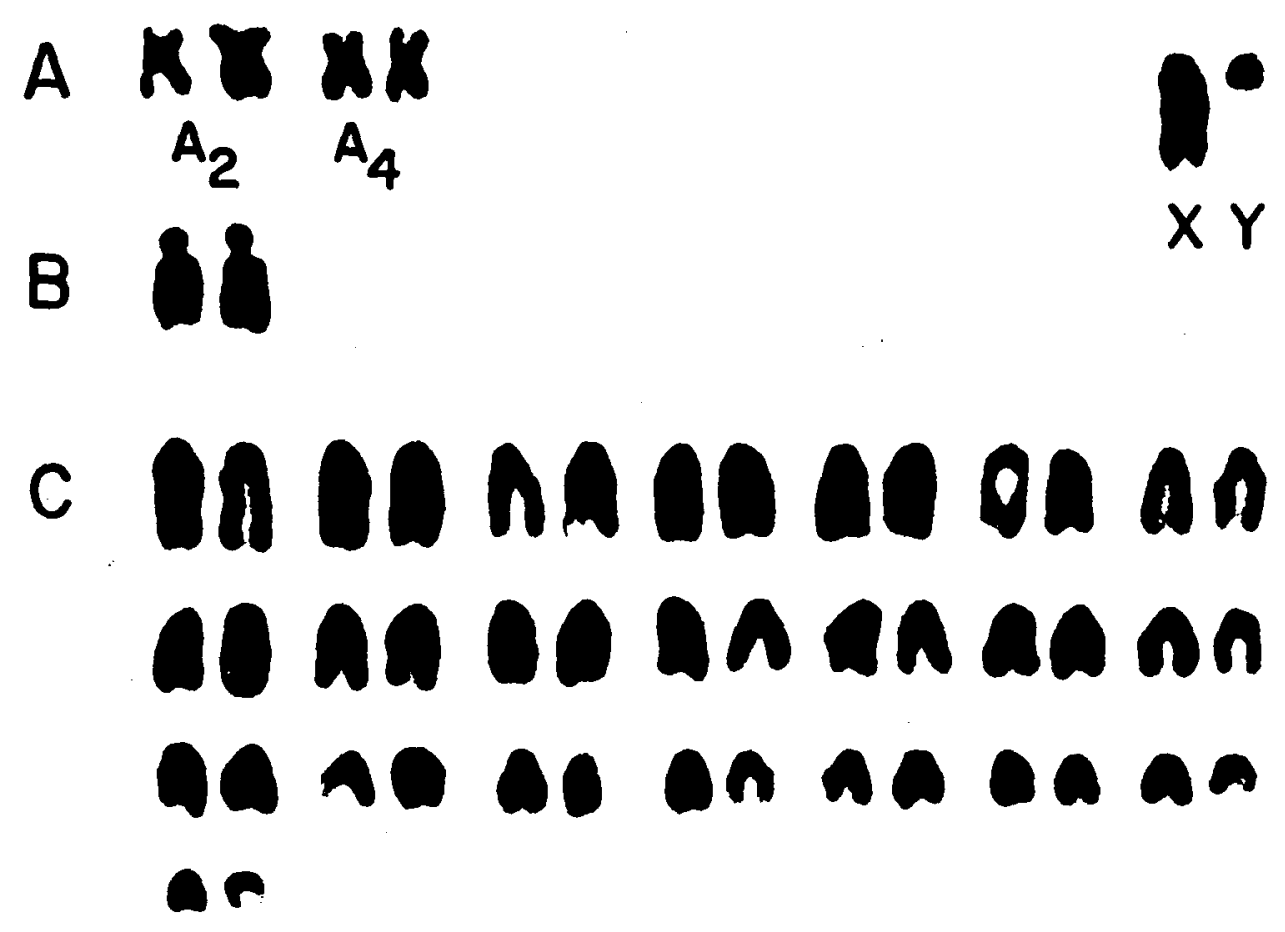

F18. 2. Karyotype of Perognathus goldmant-race $\alpha$. Male. JLP $1656.17 .5 \mathrm{mi}$. S. Alamos, Sonora, Mexico. 
Group C: 22 pairs of acrocentrics grading in size from large to small.

$\mathrm{X}$ : large acrocentric.

Y: small acrocentric. ...

Diagnosis: The significant: features of this karyotype when compared to those of other races include: (1) 2n=52, $F N=54$; (2) Group $A$ biarmed elements $A_{2}$ and $A_{4}$; and (3) the acrocentric X-chromosome. Three hybrid individuals between races $\alpha$ and $\delta$ have been examined from two localities (20 miles south of Alanos and 1 mile east of Presa. Josepfa ortiz). These individuals are karyotypically intermediate between the two races $(2 n=51)$, as would be expected (F1g. 3). Geographic distribution. liembers of this race $(N=174)$ have been trapped frorn 32 localities in southern Sonora and northern Sinaloa. Distribution is sharply delimited by the major rivers in the area (1.e., Rio Mayo, Rio Cuchijaqui, and Rio Fuerte), and contact with adjacent races is known from several localities along each of these streams. Contiguity is evidenced with Race- $\gamma$ on the north along the Rio Mayo as far east as Presa Mocuzari, with Race-d along the Rio Cuchifaqui to the east and south of Alamos, ond with Race- $\beta$ along the Rio Fuerte on the south, presumably from its mouth to the junction with the Rio Cuchijaqui (Figs. 1. 4, and 5).

Ecological distribution. The race primarily inhabits thornscrub (1.e., thorn forest of Gentry 1942 and Leopold 


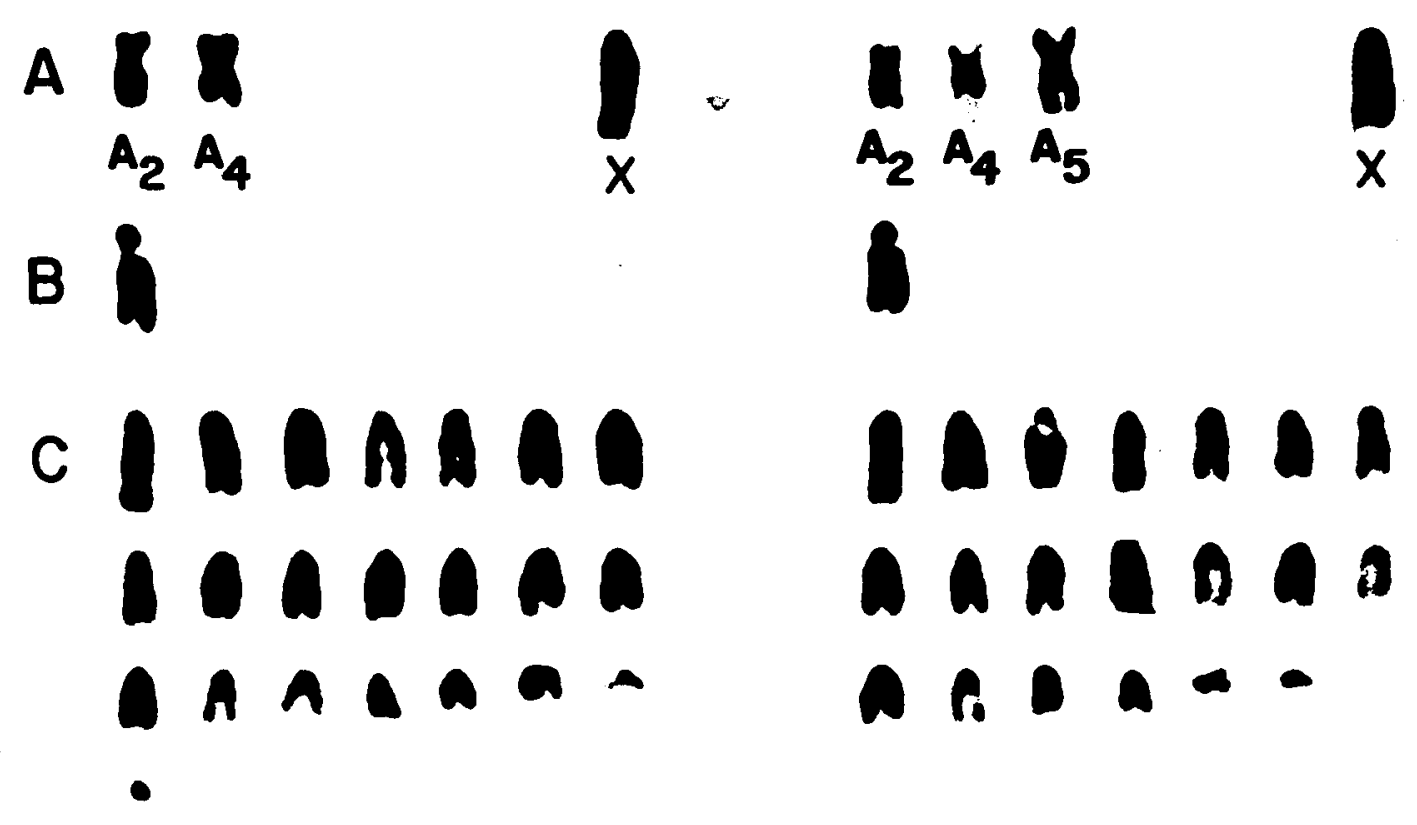

F1g. 3. Karyotype of Perognathus goldman1-race $\alpha$ and Perognathus goldmani-race $\delta$ hybrid. Female. JLP 1712. Ca. 1 mi. E. Presa Josepra Ortiz (by rd.), Sinaloa, Mexico. 


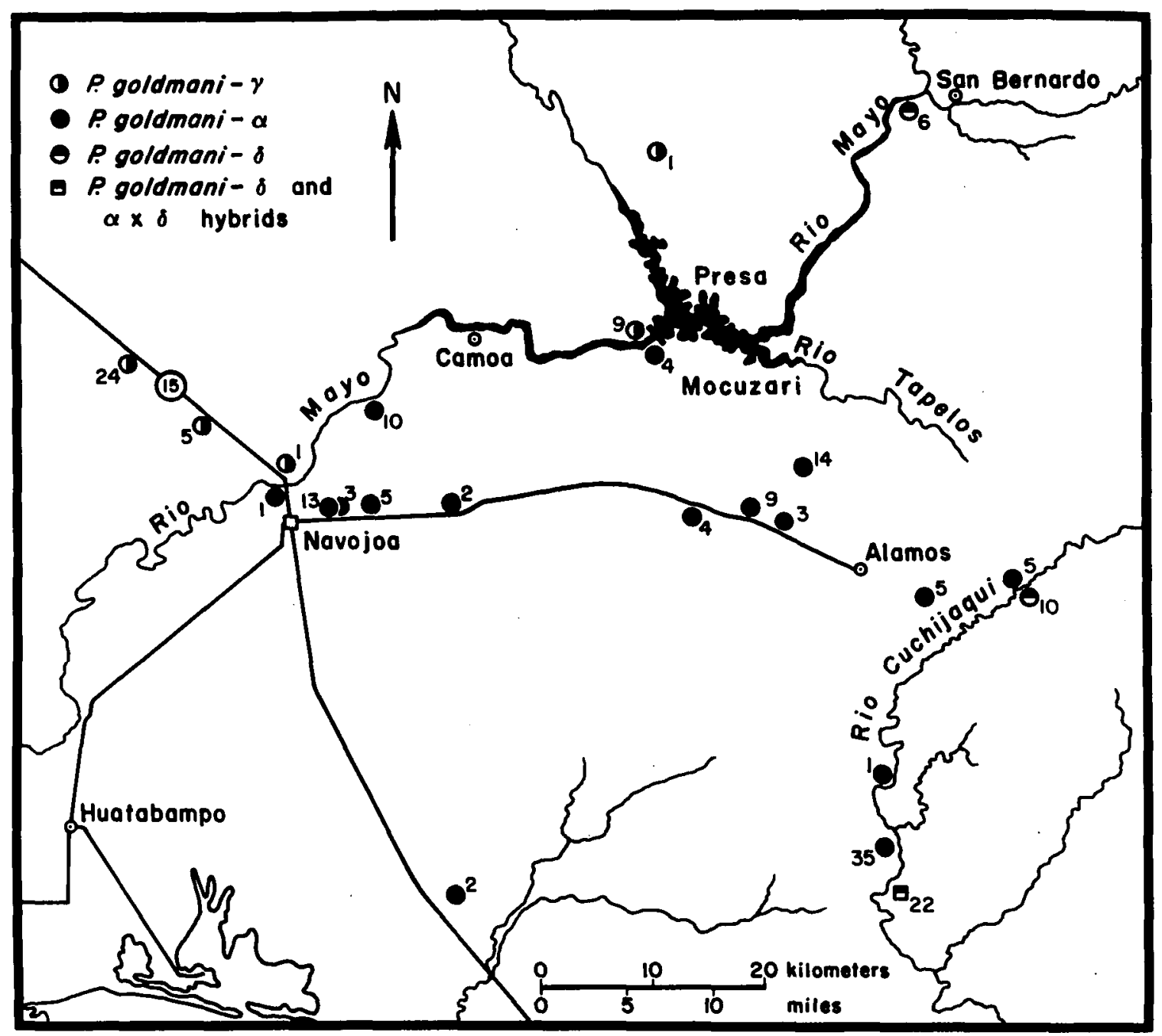

Fig. 4. Map of the Rio Mayo and adjacent Rio Cuchijaqui drainages in southern Sonora, Mexicc, detailing localities and sample sizes for three chromosome races of P. goldmani. 


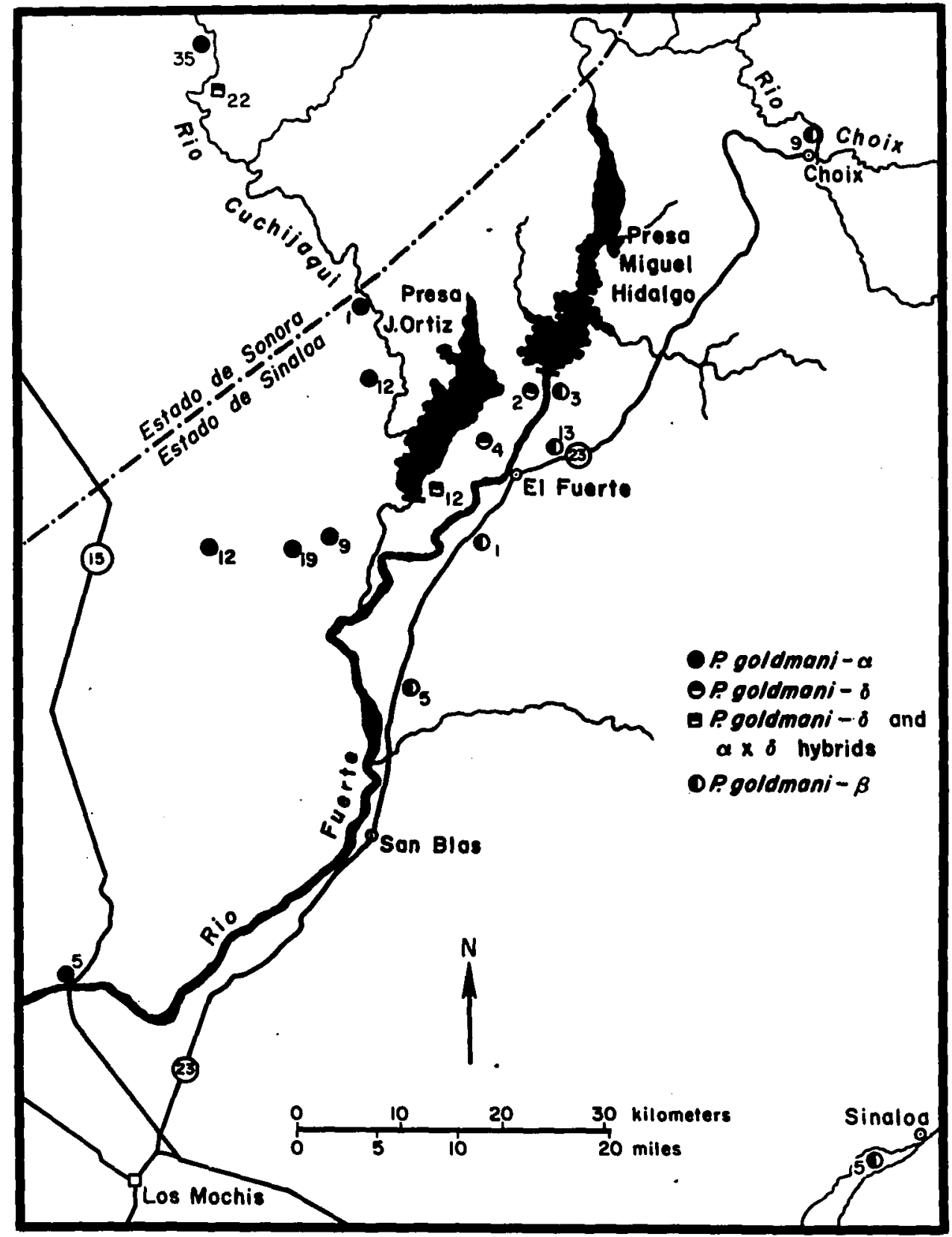

Fig. 5. Map of the Rio Fuerte drainage in southern Sonora and northern Sinaloa, Mexico, detailing localities and sample sizes for three chromosome races of $\underline{P}$. goldmani. 
1950) around Navojoa and south along the coast. This thick scrub, dominated by thorny leguminous trees and tree and shrub cacti, grades into short-tree forest (Gentry 1942) to the east in the foothilis of the sierra Madre occidental. Fully-developed short-tree forest communities, reaching heights of over 60 feet, are restricted to north and west facing slopes as well as canyon bottoms. The majority of the vegetation assemblages in this area mapped as tropical deciduous forest (=short-tree forest) by Leopold (1950) actually have a considerably more xeric and stunted appearance.

In all areas, the species is most abundant in the soft alluvial soils, but is uncommon in riporian communities, along river texraces, or on rocky slopes. Throughout the range of $\underline{p}$. Goldmani avay from the coastal areas, the species is almost completely replaced in riparian communities and in the more mesic, fully-developed short-tree forest by the sibling species, $\underline{P}$. artus.

\section{Perognathus goldmani- $\beta$}

Karyotypic description. The diploid number is 56 . the fundamental nuraber is also 56. The complement (Fig. 6) can be described as follows:

Group A: 1 pair of small metacentrics (designated $\left.A_{1}\right)$.

Group B: 1 pair of "raboit-sar" acrocentrics. 


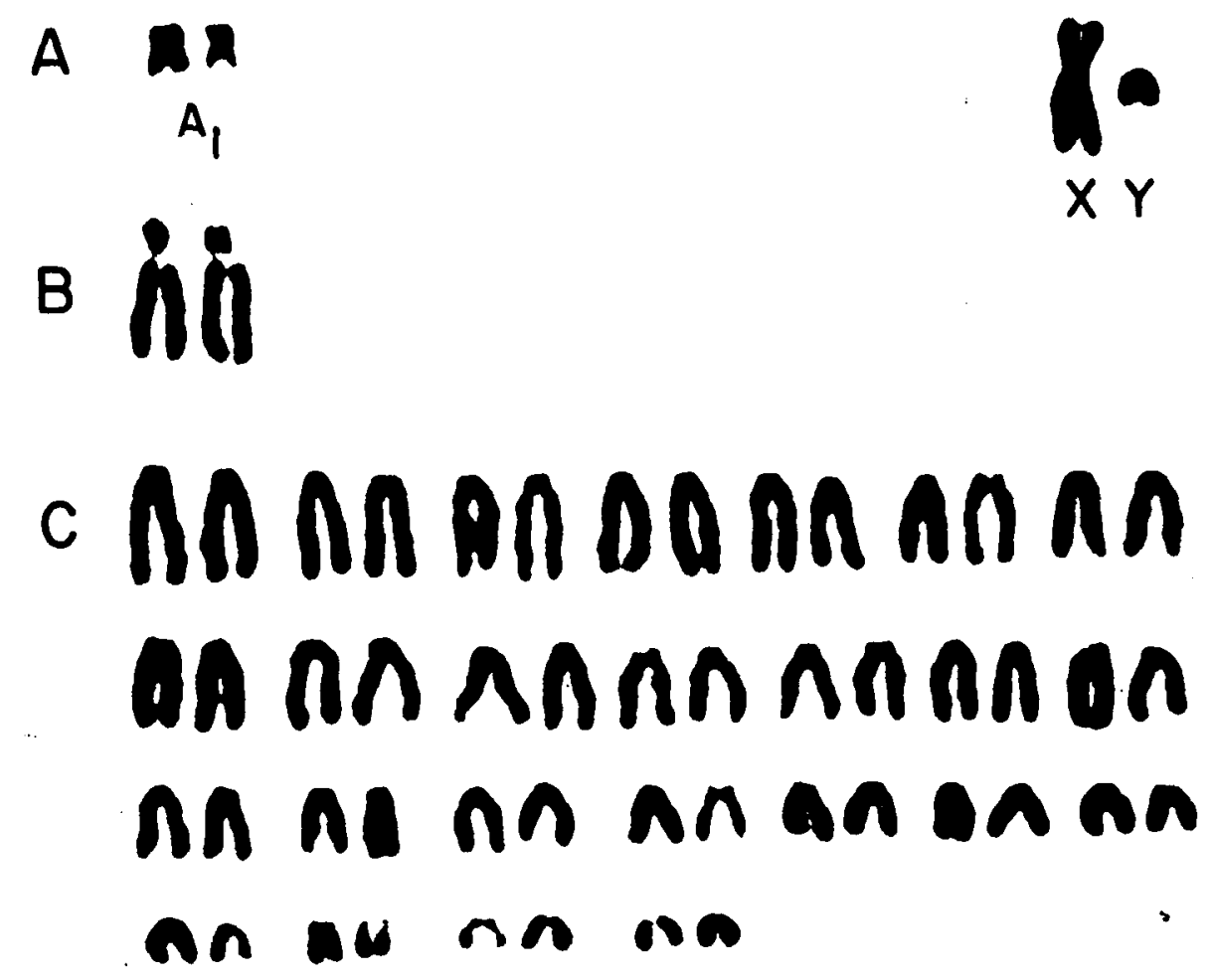

Fig. 6. Karyotype of Perognathus goldman1-race $\beta$. Male. JLP 992. South bank Rio Fuerte, ca. 1 mi. W. Presa Miguel Hidalgo, Sinaloa, Mexico. 
Group c: 25 pairs of acrocentrics grading in size froin large to small.

X: large submetacentric.

Y: small acrocentric.

Dlagnosis. While the chromosome complements of the other five races are quite similar, $\underline{P}$. goldmani- $\beta$ is strikingly distinct in several aspects. In addition to having a higher fundamental number (56 instead of 54), it can be distinguished by the single small pair of metacentric Group A autosomes (chromosome $A_{1}$ ) which is not present in any other race. The large submetacentric $\mathrm{X}$-chromosome is the same as in races $\epsilon, \theta$, and $\gamma$.

Geographic distribution. The race $(N=36)$ has been trapped from six localities essentially covering the entire range of $\underline{p}$. goldmani south of the Rio Fuerte in northern Sinaloa (FIgs. 1 and 5). The locelity near Choix represents the most eastern point and that near Verdura the most southern point of the distribution of the species, as mapped by Anderson (1964). Contact is made between races $\beta$ and $\alpha$ along the lower Rio Fuerte eastward to 1 ts junction with the Rio Cuchijaqui, and between races $\beta$ and $\delta$ from that point farther to the east along the upper Rio Fuerte. Ecological distribution. The general habitat is thornscrub resembling short-tree forest (Gentry 1942 and R. S. Felger, personal comnunication) from Los Mochis south 
along the coast, grading into xeric aspects of the tropical deciduous forest to the east in the upper Rio Fuerte valley. The lower reaches of this valley, as well as that of the adjacent Rio Sinaloa valley, are currently under extensive agriculture. Moreover, large areas within the tropical deciduous forest have taken on scrub appearances because of agricultural or overgrazing disturbances. The species is uncommon in corpletely disturbed sites, but is very abundant in the loose, clay solis of areas with more natural vegetation. In the areas east of Choix and south of Verdura, p. goldmang. is replaced by $\underline{P}$. entus, even though the forest and scrub habitats are continuous. The replacement of $\underline{P}$. goldmani by $\underline{P}$. grtus away from the coastal plain is correlated with shifts in humidity and vegetation (Anderson 1964).

\section{Perognathus goldmani- $\gamma$}

Karyotypic description. The diploid number is 52 , the fundamental number 54. The karyotype (F18. 7) can be described as follows:

Group A: 2 pairs of medium submetacentrics (designated $\mathrm{A}_{2}$ and $\mathrm{A}_{4}$, respectively).

Group B: 1 pair of "rabbit-ear" acrocentrics.

Group C: 22 pairs of acrocentrics grading in size from large to small.

$\mathrm{X}$ : large submetacontric.

Y: small acrocentric. 

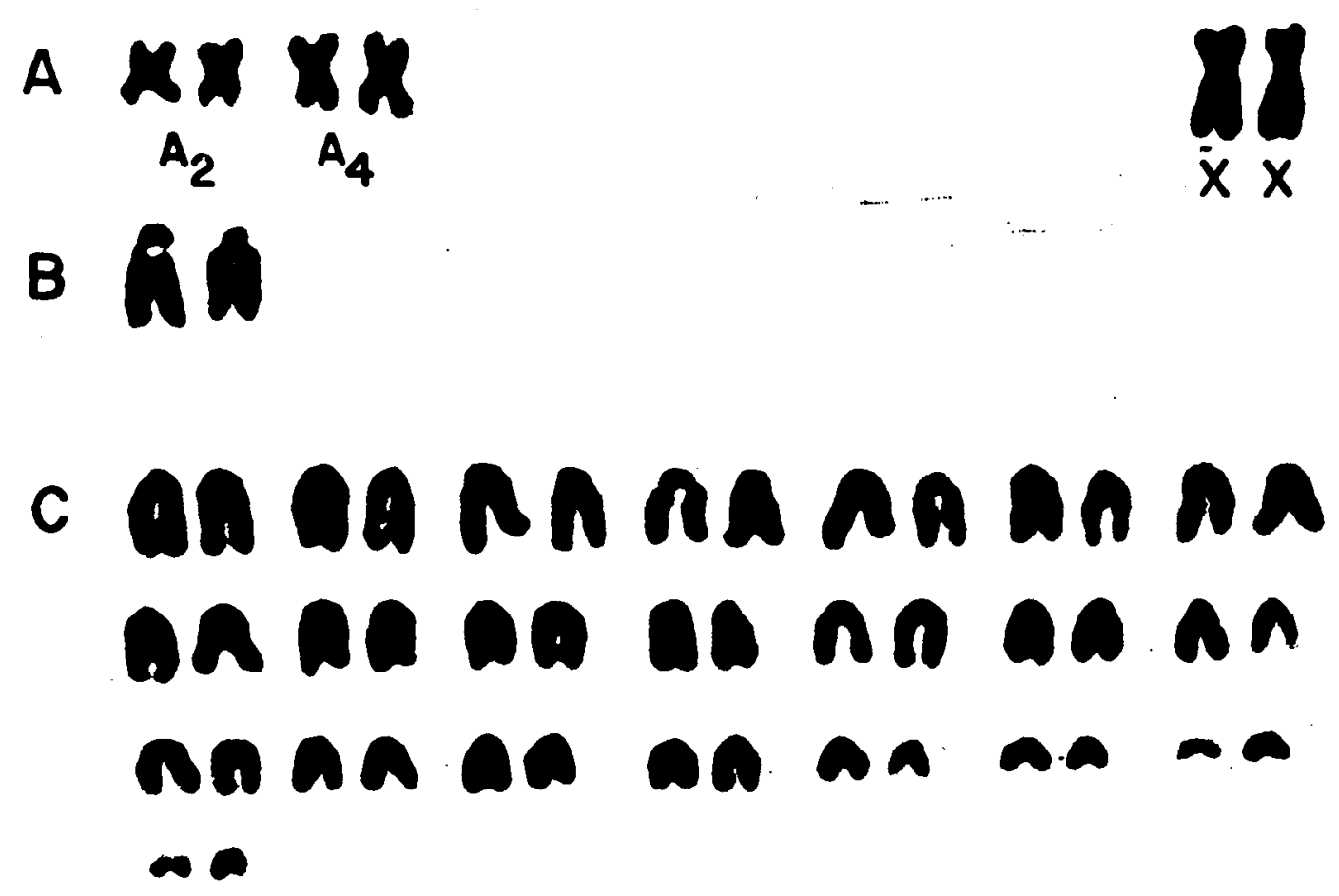

F1g. 7. Karyotype of Perognathus goldmani-race $\gamma$. Female. UA 15901. $16 \mathrm{ml}$. N. Navojoa (by rd.), Sonora, Mexico. 
Diannosis. The karyotypes from sampled individuals are Identical to those belonging to Race- $\alpha$, except that the $X$-chromosome of Race- $\gamma$ is a large submetacentric and that of Race- $\alpha$ is a large acrocentric. Both races have the same number of Group $C$ autosomes and the same two palrs of Group A biarned elements (chromosomes $\mathrm{A}_{2}$ and $\mathrm{A}_{4}$ ).

Geographic distribution. The race $(N=44)$ is known from six populations ranging from Presa Alvaro Obregon north of Cuidad obregon, south and east of the Rio Yaqui to the north bank of the Rio Mayo froln Navojoa to at least Tepahui (F1gs, 1 and 4). The race presumably extends eastward into the foothills of the sierra ladre occidental along the Sonora-Chihuahua border, the easterin edge of the species range. Contact is established with Race- $\alpha$ along the Rjo Mayo from Navojoa to Presa Mocuzari. Assumed contact is also made with Race- $\delta$ east of Presa Mocuzari along the upper Rio layo. The northern distributional linits and consequently contact points with Race- $\epsilon$ are unknom at present.

Ecological distribution. Habitats of the race to the north of the Rio Nayo are continuous in kind and composition with those occupled by Race- $\alpha$ to the south of this river. However, around Presa obregon, the species (and race) departs radically from the more typical southern habitat conditions. In this area rocky soils, particularly on low incline slopes, are the characteristic habltat for 
the species. The vegetation of the general region of the Rio Yaqui valley is included in the Foothills of Sonora Section of the Sonoran Desert (Shreve and Higgins 1964) and is characterized by heavy stands of trees and shrubs, the species composition of which is inalcative of strone thornscrub influences from the south.

\section{Perognathus goldinan1- $\delta$}

Karyotyple description. The diploid number is 50 , the fundamental nurber 54. The karyotype (Fig. 8) can be described as follows:

Group A: 2 paixs of medium subrnetacentrics (desifnated $A_{2}$ and $A_{4}$ ) and 1 pair of large submetacentrics (designated $A_{5}$ ).

Group E: 1 pair of "rabbit-ear" acrocentrics.

Group c: 20 pairs of acrocentrics grading in size from laxge to small.

X: large acrocentric.

Y: small acrocentric.

Diacnosis. The chromosome corplement is most similar to that of Race- $\alpha$. Both contain the large acrocentric $X-$ chromosome and the $A_{2}$ and $A_{4}$ biarmed elements of Group $A$. Race- $\delta$, however, possesses an additional Group A biarmed. pair $\left(A_{5}\right)$, lacks two pairs of Group $C$ acrocentrics, and has a lower diploid number. 


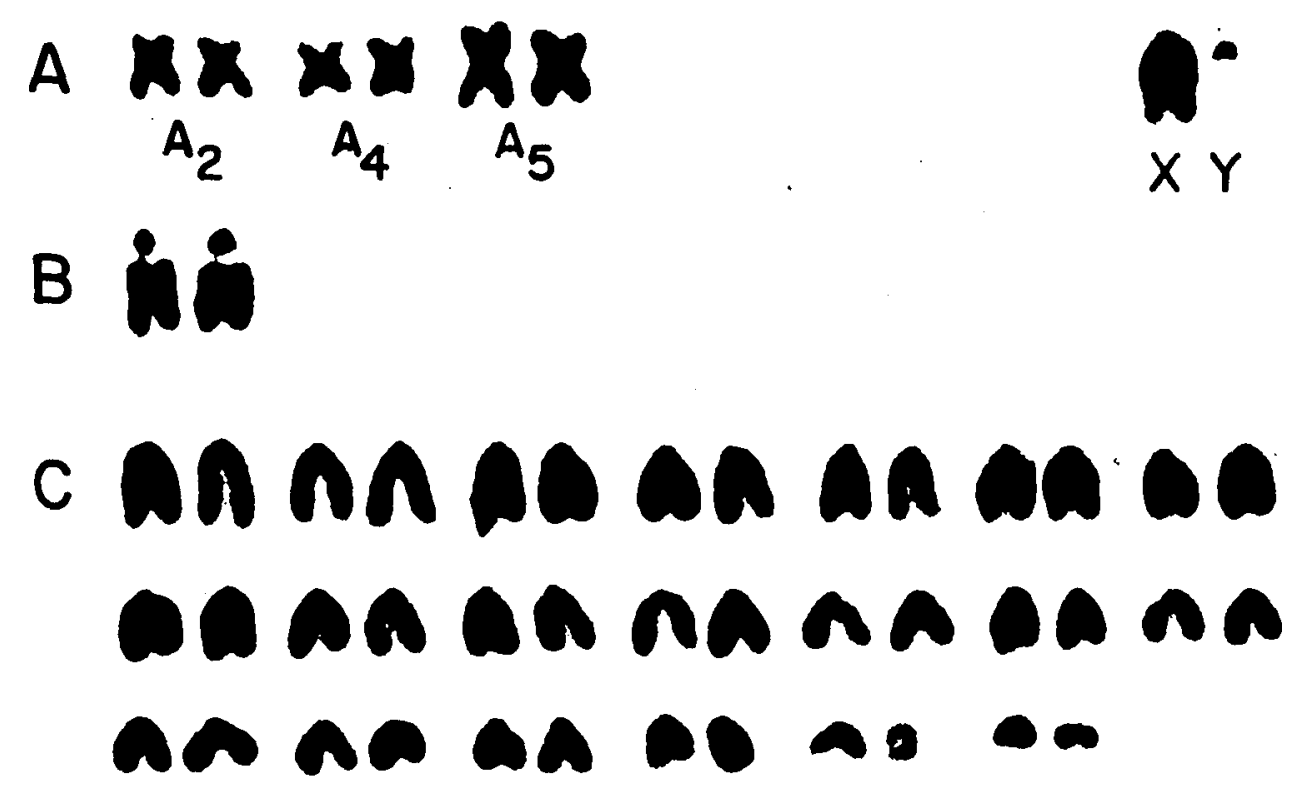

F18. 8. Karyotype of Perognathus goldman1-race $\delta$. Male. JLP 1040. South bank Rio Mayo at Las Panelas, Sonora, Mexico. 
Geographic distribution. Individuals of the race

$(N=53)$ have been examined from six localities. The race is restricted on the north and northivest by the Rio Mayo, to the west by the Rio Cuchijaqui (and Presa Josepfa Ortiz), and to the south by the Rio Fuerte (and Presa Miguel Hidalgo). Extension eastward into the foothills of the Sierra Madres between the headwaters of the Rio Mayo and Rio Fuerte is presumed (Figs. 1, 4, and 5). The range of the race abuts those of Race- $\gamma$ along the upper Rio liayo, Race- $\alpha$ along the Rio Cuchijaqui, and Race- $\beta$ along the upper Rio Fuerte. Contact with Race- $\alpha$ between the Rio Mayo and Rio Cuchijaqui is presumably along the Rio Tapelos. As mentioned above, hybrids are known between races $\alpha$ and $\delta$ from two localities of contact along the Rio Cuchijagui.

Ecological distribution. The race is confined almost exclusively to short-tree forest habitats throughout its known range, except for disturbed areas within that forest which provide a definite scrub appearance. The animals are very abundant in soll types ranging from soft clay alluvium to loose solls with scattered small rock material. Again, the species is uncommon in riparian communities or agricultural areas. Within the former habitat, replacement by $\underline{p}$. axtus is very pronounced. 


\section{Perosnathus goldmant- $\epsilon$}

Karyotypic description. The diploid number is 54. the fundamental number is 54. The karyotype (Fig. 9) can be described as follows:

Group A: 1 pair of medium submetacentrics (designated $\mathrm{A}_{2}$ ).

Group B: 1 pair of "rabbit-ear" acrocentrics.

Group C: 24 pairs of acrocentrics grading in size from large to small.

$\mathrm{X}$ : large submetacentric.

Y: small acrocentric.

Diagnosis. The karyotype is most similar to those of races $\gamma$ and $\theta$, but is distinguished by a higher diploid number, the single Group $A$ autosome $\left(A_{2}\right)$, and two additional Group $C$ acrocentric pairs. The large submetacentric $X-$ chromosome is the same as in races $\beta, \gamma$, and $\theta$.

Geographic distribution. The race $(N=7)$ is known only from two major localities (Tonichi and Moctezuna), both at the extreme northwestern edge of the species range in the middle Rio Yaqui and Rio Moctezuma valleys. Presumably the race as well as the species is restricted on the west by several small mountain ranges, and their characteristic desertscrub vegetation. The most effective barrier on the north is the Sierra de Nacozari (Findley 1967). The castern extension of both the race and the species 1 s undetermined 


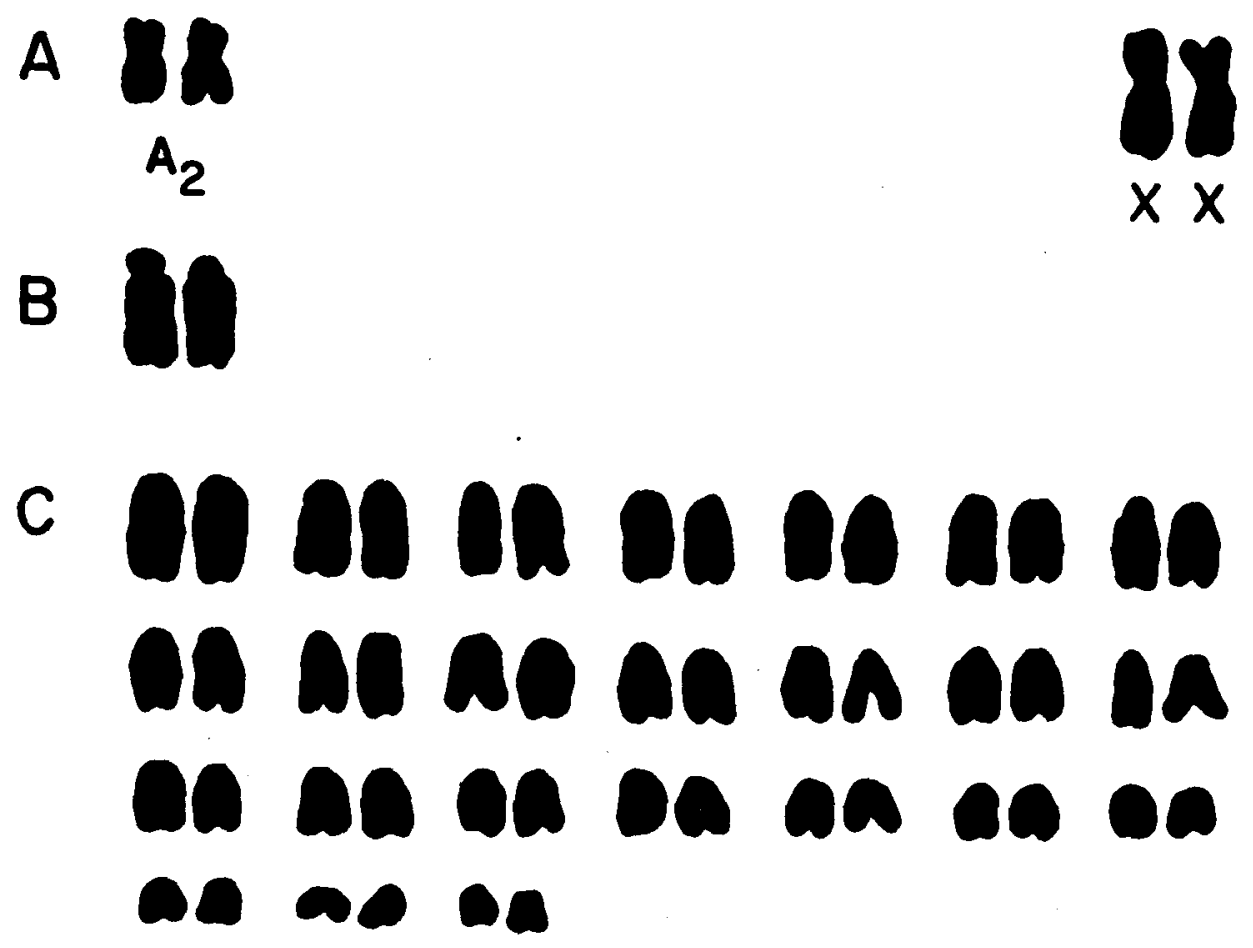

F1g. 9. Karyotype of Perognathus goldmant-race $\epsilon$.
Female. UA 15632 . Ca. $1 \mathrm{mi}$.
Mexico. 
at present, and at least the species may enter Chihuahua following tributaries of the Rio Yaqui (1.e., Rio Harros and Rio Papagochic). Contact to the south with. Race-r must lie between Tonichi and Presa Obregon. Here, the most effective barrier is probably the lack of continuous favorable habltat.

Ecological distribution. Unlike more typical situations to the south, P. goldmani in the Rio Yaqui basin is restricted to rocky slopes and rock-strewn pavements (Findley 1967) in which the vegetation is a mixture of desertscrub elements from the north and west and thornscrub elements from the south (Shreve and Wiggins 1964. Wright 1967). The region is placed within the Foothills of sonora Section of the Sonoran Desert by. Shreve (Shreve and Wiggins 1964). The presence of the desertscrub pocket mouse, $\underline{P}$. penicillatus, in the more rock-free alluvial soils is perhaps a major factor for the shift in habitat by $\underline{\text { P. gold- }}$ mani onto rocky slopes. Presumably the northern extension of the species is restricted by the loss of sultable habitat in the Sierra de Nacozari and north, as well as contact with the saxicolous xerophylic pocket mouse, P. intermedius.

\section{Pexognathus goldmani- $\theta$}

Karyotypic description. The djploid number is 52 , the fundamental number 54. The kaxyotyoe (Fig. 10) can be described as follons: 
24

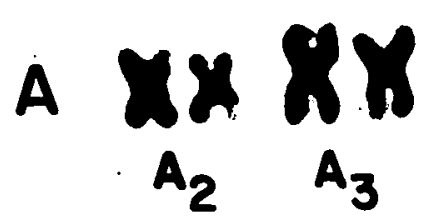

$\underset{X Y}{X a}$

$B 8$

c no an an no an ighro

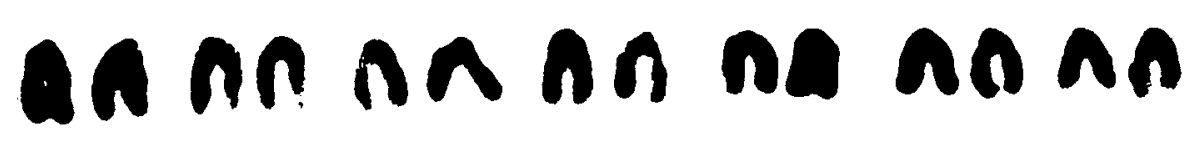
an an aAab an aAsa

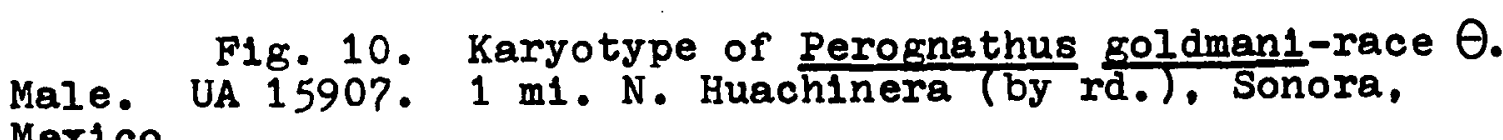

Mexico. 
Group A: 1 pair of medium submetacentrics (designated $A_{2}$ ) and 1 pair of large metacentrics (designated $\mathrm{A}_{3}$ ).

Group B: 1 pair of "rabbit-ear" acrocentrics.

Group C: 22 pairs of acrocentrics grading in size from large to small.

$\mathrm{X}$ : large submetacentric.

Y: small acrocentric.

Diagnosis. The karyotype is nearly identical to that of Race- $\gamma$, having the same diploid number, fundamental number, and numbers of each group of autosomes, as well as the submetacentric $\mathrm{X}$-chromosome. Distinction can be easjily seen between the two races, however, by examination of the Group A biarmed elements. Race- $\theta$ has two pairs of obviously unequal size while Race- $\gamma$ has two pairs of equal size. One of these elements (chromosome $A_{2}$ ) is shared by both races. Geographic distribution. The meager sarnple $(\mathrm{N}=2)$ of the race was obtained from two localities, both near the Sonoran town of Huachinera in the extreme upper Rio Bavispe drainage (Fig. 1). These localities represent notable extensions ( 75 miles) in the range of $\underline{\text {. }}$ goldmani and extend its range to include a drainage system previously unknown fox the species (see map, Hall and Kelson 1959: 502, and discussion in Findley 1967). Both the race and the species proper are probably restricted to the Rio Bavispe 
valley because of the surrounding high mountains to the east, south, and west, and general absence of suitable habitat outside the immediate valley floor. Race- $\theta$ may represent a geographic isolate of the species, as its habitat is not continuous throughout the Rio Bavispe valley. Contact with Race- $\epsilon$ to the southwest 1s, therefore, improbable.

\section{Ecological distribution. At Huachinera, Race- $\theta$}

was trapped within a prosop1s-Juniperus monosperma association on the pebbly soils of the river terrace. At Aribabi, the characteristic habitat is lower oak woodand within the broad, middle elevation valleys. Here, the fine sandy. soil is continuously interrupted with abundant rock material scattered throughout the thin soll layer. At both localities the roce was associated with the predominantly woodland and riparian species, Peromyscus boylei.

Perognathus goldmani is seemingly linited in this extreme northern part of its range by xeric communities and hence is restricted to riparian associations and the lower montane woodlends. The inhabitation of both higher elevations and their concomitant vegetation assemblages is typical for the more subtropical species of vertebrates which meet the desert in the northern parts of the1r range (Martin 1963). 


\section{Peromathus artus}

Kaxyotypic description. A karyotype of the species has been presented elsewhere (Patton 1967a, Fig. 3). The diploid number is 54 , the fundamental number 54. The chromosome complement (Fig. 11) can be designated as follows:

Group A: 1 pair of large submetacentrics (designated $A_{6}$ ).

Group B: 1 pair of "rabbit-ear" acrocentrics. Group C: 24 pairs of acrocentrics grading in size from large to small.

X: large submetacentric.

Y: small acrocentric.

Diagnosis: The karyotype is very sinilar to those of all P. goldmani races, particulariy Race- $\epsilon$ and the hypothetical ancestral arrangement. Two features of the $\underline{P}$. artus karyotype, hovever, clearly distinguish it from any of the six $\underline{\text {. }}$ goldrnani complements: (1) the large submetacentric Group $A$ autosome $\left(A_{6}\right)$, and (2) the single pain of minute (dot) acrocentrics in Group $C$. No chromosomal variation has been recorded within the species ( $N=43$ from seven localities). 


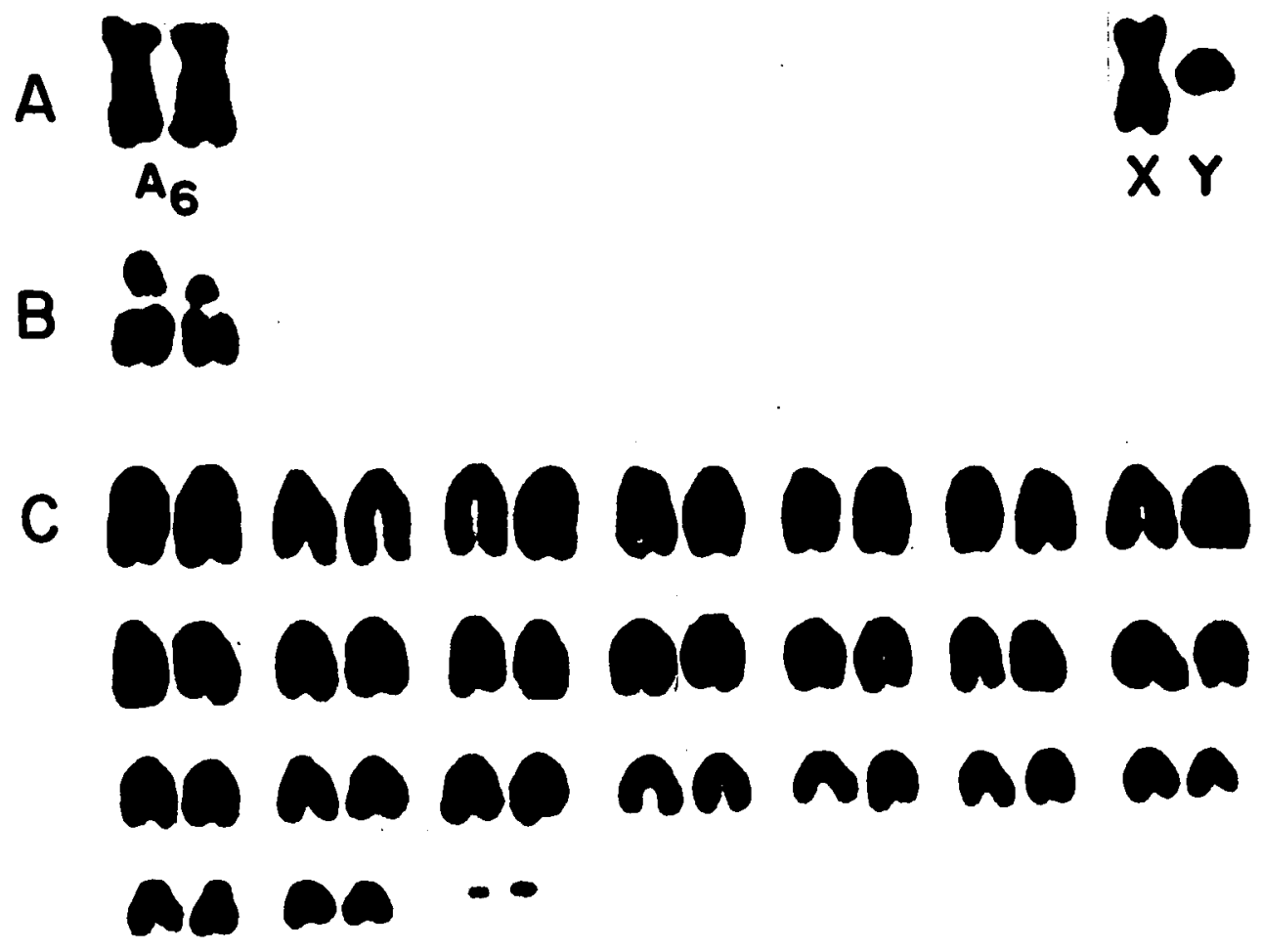

F1g. 11. Karyotype of Perognathus artus. Male. JIP 1028. East bank R10 Cuch1 jaqu1, ca. 12 m1. E. Alamos, (by ra.), Sonora, Mexico. 


\section{CHROMOSOIE PHYLOGENY}

The constancy of the fundamental number despite changes in diploid number within the $\underline{\underline{p}}$. goldmani complex of chromosome variants, strongly suggests a mechanisra involving Robertsonian transformations (1.e., "fusions" and "dissociations"). Such a mechanism would involve changes in the number of centromeres present in each population karyotype, but would not alter the number of chromosome arras (or fundamental number). While there is general concurrence that the two processes, "fusion" and "dissociation", are not opposite equivalents, both are known to have occurred in natural populations of animals (White 1957, 1965; Wahrman and O'Brien 1956). Of the two cholces, however, whole-aria translocations (=fusions) axe generally considered most frequent since thexe are fewer obstacles present for their formation (i.e., for dissociations one must either account for a new centromexe, or risk the formation of iso-chromosones through the transverse division of the original centromere). The Robertsonian process of "centric fusion" is consiclered the most probsble mechanism for explaining the present occurrence of four of the s1x chromosome races of $p$. 
goldmant. This is based on the higher observed frequency In studies conducted to date ( see general reviews of John and Lewis 1966, Patterson and Stone 1952, Wurster and Benirschise 1968), as well as greater relative ease in accomplishment. This assumption is supported by geographic distribution and population ecology of the races of $\underline{P}$. goldmani. ( see below).

Robertsonian fusions lead to a lowering of the diplo1d number with the concomitant formation of biarmed elements from previously uniarmed ones. Hence, the most ancestral karyotype would be one which possessed the highest diploid number and in which all chromosomes were acrocentric. In $\underline{P}$. goldman1 no race has an ent1rely acrocentric complement, but two races ( $\beta$ and $\dot{\epsilon}$ ) do possess only one blarmed pair. These races do, however, differ in fundamental number and diplo1d number (56-56 and 54-54. respectively). Since the other four races have the same fundamental number as Race- $\epsilon(54)$, this can be assumed to be the ancestral condition. Consequently, an ancestral type forming the initial step in the chromosome phylogeny, with a fundamental number of 54, would necessarily have a. diploid number of 56 and an entire acrocentric autosomel complement. The ancestral condition is hypothetical for it has not been found in nature. 
The phylogeny involving the formation of $\mathrm{six}$ chromosome races of $\underline{P}$. goldmani from the hypothetical ancestral type is depicted in Fig. 12. Each race represents a single step transformation largely of a Robertsonian nature but also including two pericentric inversions. The submetacentric $X$-chromosome is considered ancestral for two reasons: (1) it is characteristic for all other members of the cenus examined to date (17 species, Patton 1967a, b, unpubl1shed data), and (2) the two most primitive races ( $\beta$ and $\epsilon$ ) have the submetacentric element, and the most derived race $(\delta)$ has the acrocentric $X$.

Two lines of evolution branched from the hypotheti. cal ancestor. The first led only to Race- $\beta$ via a pericentric inversion in a small autosore (chromosome $A_{1}$ )-wence the maintenance of the same diploid number $(56)$ as the ancestral race but an increase of two in the fundamental nuraber ( 54 to 56). The second branch ultinately produced all other known races through a series of four autosomal fusions and a pericentric inversion in the $\mathrm{X}$-chromosome. Thus, Race- $\epsilon$ is a single step removed from the ancestral type as a result of one centric fusion to form the single medium submetacentric Group $A$ pair (chromosome $A_{2}$ ), and so forth (consult Fig. 12).

Because of the presumed role of $\underline{P}$. artus in the formation of the chromosornal variants of $\mathrm{P}$. Foldinant 
Fig. 12. Diagrammatic chromosome phylogeny of the six chromosome races of $\mathrm{P}$. goldmani.

The non-homologous chromosomes involved in the six transformations are numbered separately in the hypothetlcal ancestor. The karyotypic relationship of $\underline{p}$. artus to the ancestral condition as well as to the races of P. goldmant is also shown. None of the transformations that occurred in the $\underline{P}$. Eoldmani lineage are shared by P. artus. 


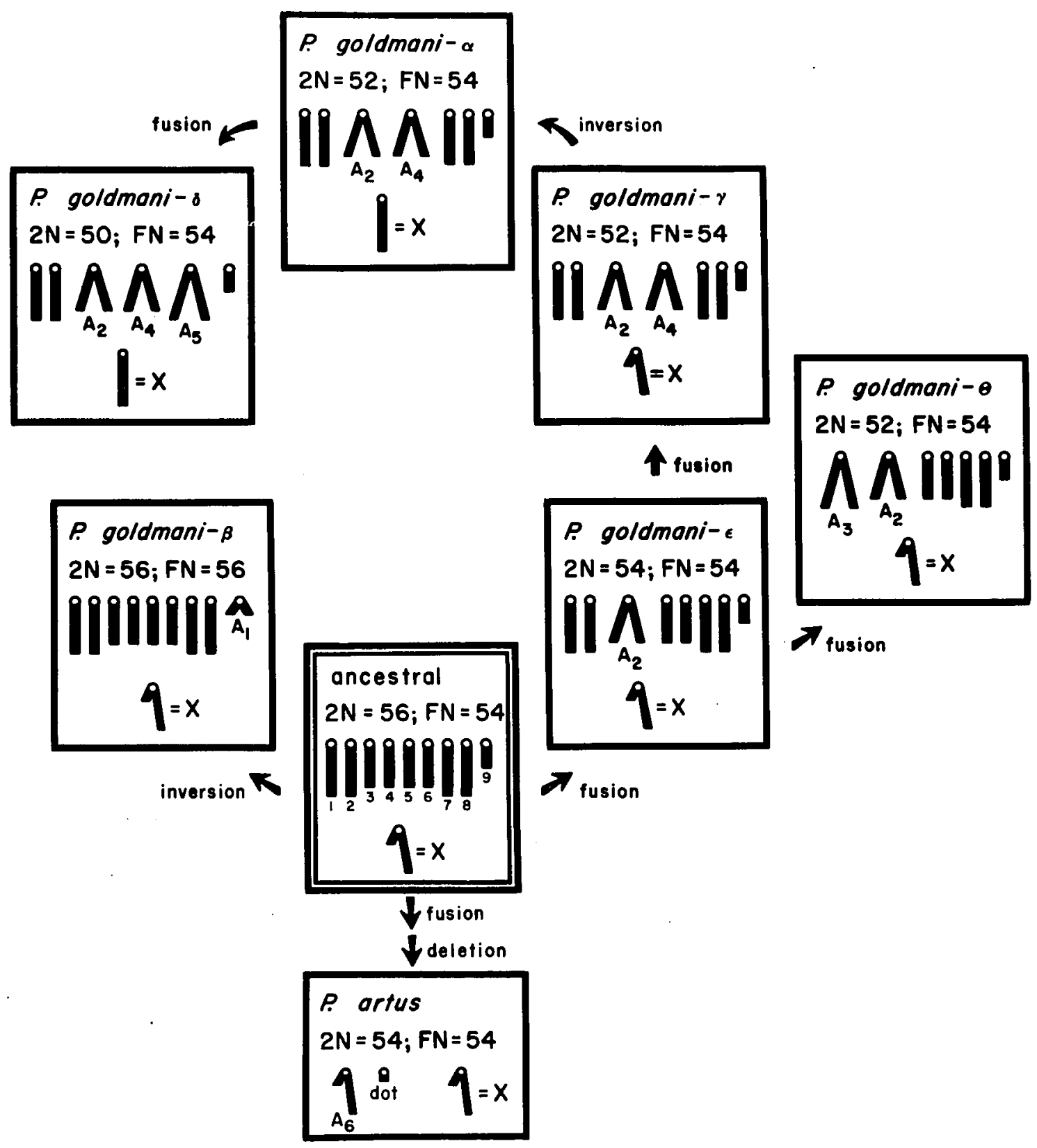

Fig. 12. Diagramatic chromosome phylogeny of the six chromosome races of $\underline{\underline{p}}$. goldmani. 
(discussed below), the karyotypic affinity of the two species is of importance. Morphological and ecological relationship has already been discussed (Anderson 1964. and above). The striking chromosomal resemblance between them has also previously been commented on (Patton 1967a). Indeed, only a single fusion and a deletion of part of a small acrocentric autosome need be required to derive artus alrectly from the hypothetical ancestral P. goldmanj. arrangement (Fig. 12). Perognathus artus maintains the ancestral type $\mathrm{X}$-chromosome and the some fundamental number of the hypothetical ancestor and the majority of the chromosome races of $\underline{P}$. goldmani. 


\section{DISTRIBUTION PATTERNS}

Under the present interpretation of the chromosome phylogeny, it is singularly evident from Fig. 1 that the two most ancestral races ( $\beta$ and $\epsilon$ ) are located on the southern and northern nargins, respectively, of the range of P. goldmani (excluding Race- $\theta$, at the noxtheastexn margin). Consequenti.y, the interior regions are occupied by the progressively more derived races, $\gamma, \alpha$, and $\delta$. It is also apparent that beginning in the north with Race- $\epsilon$, there is a sequentiol geographic positioning of the races to the south following exactly the path of chromosome evolution (i.e., to the south of Race- $\epsilon$ is Race- $\gamma$, one step from $\epsilon_{;}$to the south of Race- $\gamma$ is Race- $\alpha$, again one step removed, and so forth). Thererore, the phylogenetic and geographic positions of the races are identical (compare Figs. 1 and 12). Each race borders not only on the one from which it arose, but also on the one to which it gave rise. If one, hovever, were not to accept the phylogeny based on fusions, and instead maintained dissociations as the predominant mechanism, correlation between geography and phylogeny would not occur. In a dissociation interpretation the karyotypes displaying the highest diploid 
number and number of acrocentrics would be considered derived, not ancestral. Therefore, races $\beta$ and $\epsilon$ would be interpreted as the most karyotypically advanced races, and one could allow for the derivation of Race- $\beta$ from $\epsilon$ Race- through a "fission" of chromosome $\Lambda_{2}$ and an inversion to form chromosome $A_{1}$. Geographically, this interpretation seems least likely, for the two races are currently separated by some 200 miles and an intervening three races, not to mention the great differences in habitat preferences exhibited by the two forms (see above).

A phylogenetic hiatus (but not a geographical one) is present along the Rlo Fuerte in northern Sinaloa where the derived races, $\alpha$ and $\delta$, meet the ancestral Race- $\beta$. This situation can, however, be explained by the proposed phylogeny, since Race- $\beta$ was derived fxom the hypothetical ancestor by a different path than the lineage which gave rise to the races geographically adjacent to 1 t. 
ECOLOGY AND POPULATION DYNAMICS OF CONTACT ZONES

In each area where two races are known to be contlguous, they are separated by water barriers of varying sizes, from broad, swift-flowing rivers, such as the Rio Fuerte, to smaller, now intermittently flowing streans, as the Rio Cuchijaqui. The zones of contact along these streams were examined at six localities (Figs. 4 and 5): at Navojoa and Presa Mocuzari on the Rio Mayo (between races $\gamma$ and $\alpha$; the $R 10$ Cuchijagui at 12 miles east and 20 miles south of Alamos and at Presa Josepía Ortiz (between races $\alpha$ and $\delta$ ); and in the vicinity of Presa Miguel Hidalgo on the Rio Fuerte (between races $\delta$ and $\beta$ ). If the disturbed habitats on one or both sides of a river at a given locality can be excluded (since the disturbance is presumably due to the recent erforts by man), the habitat in terms of plant species composition and soll type is identical on both sides of rivers whose banks support different chromosome

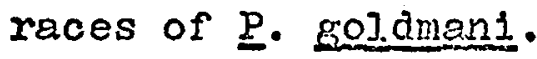

At all but two localities, most of the natural vegetation (i.e., thornscrub or short-tree forest, depending upon locality) has been removed, or severly altered, to considerable distances on either side of a given river. The 
disturbances in these cases are predominantly from occupstion, agriculture, or overgrazing. Consequently, at Navojoa, for example, relatively undisturbed thornscrub communities are found no closer to the Rio Mayo than two miles to the north or six miles to the south. Although a few $\underline{\text { P. goldmani }}$ can be trapped within such disturbed sites, along most of the length of each river large populations are not in jmmediate contact. The present olstance separating adjacent chromosome races in most areas is, therefore, considerably greater than the actual width of a river at any given locality. Presumably, however, this was not true prior to recent occupation of the region by man.

Along numerous sections of the Rio Cuchijaqui, east and south of Alamos, no major disturbance factors are evident. Consequently, two localities on this stream (12 miles east and 20 miles south of Alamos) were examined in some detail to determine: (1) the actual width of separation of adjacent races, and the ecological factors determining this distance; (2) the amount of dispersal across the strean; and (3) the consequent results of dispersal in terms of the degree of gene exchange.

The Rio Cuchijaqui is now an intermittent stream, drying up along some stretches during late vinter through June. During and after the rainy season (July through December) water flows continuously, and the strean varies 
In width from four to twenty meters. One would suspect, therefore, that dispersal across the river in the dry season would be possible because of absence of water in some areas, if, indeed, its presence is a major factor prohibiting movement. However, trap records (involving 127 mice from three general contact localities along the Cuchijaqui) do not indicate that the presence of water. acts as a barrier. At no localities have two races been trapped within the same trap Ine, regardless of the time of year or stream conditions. Since P. goldmani prefers the soft, sandy-clay soils within the more xeric espects of the short-tree forest, the dry and rocky river bed devold of any covering vegetation may be uninviting to movement. Moreover, if one examines the actual distribution of $p$. goldmani in the areas adjacent to the stream, the width of separation between racial populations is much greater than the width of the stream 1tself, and essentially encompasses the outside width of the riparian and full shorttree forest communities bordering the stream. As was noted previously, the sibling species, P. artus, displaces P. goldmani within both the riparian association and the more mesic, fully-developed short-tree forest.

Figure 13 1llustrates diagrammatically the lateral extent of the major vegetation bands and the concomitant distribution and density of pocket mice collected vithin the 


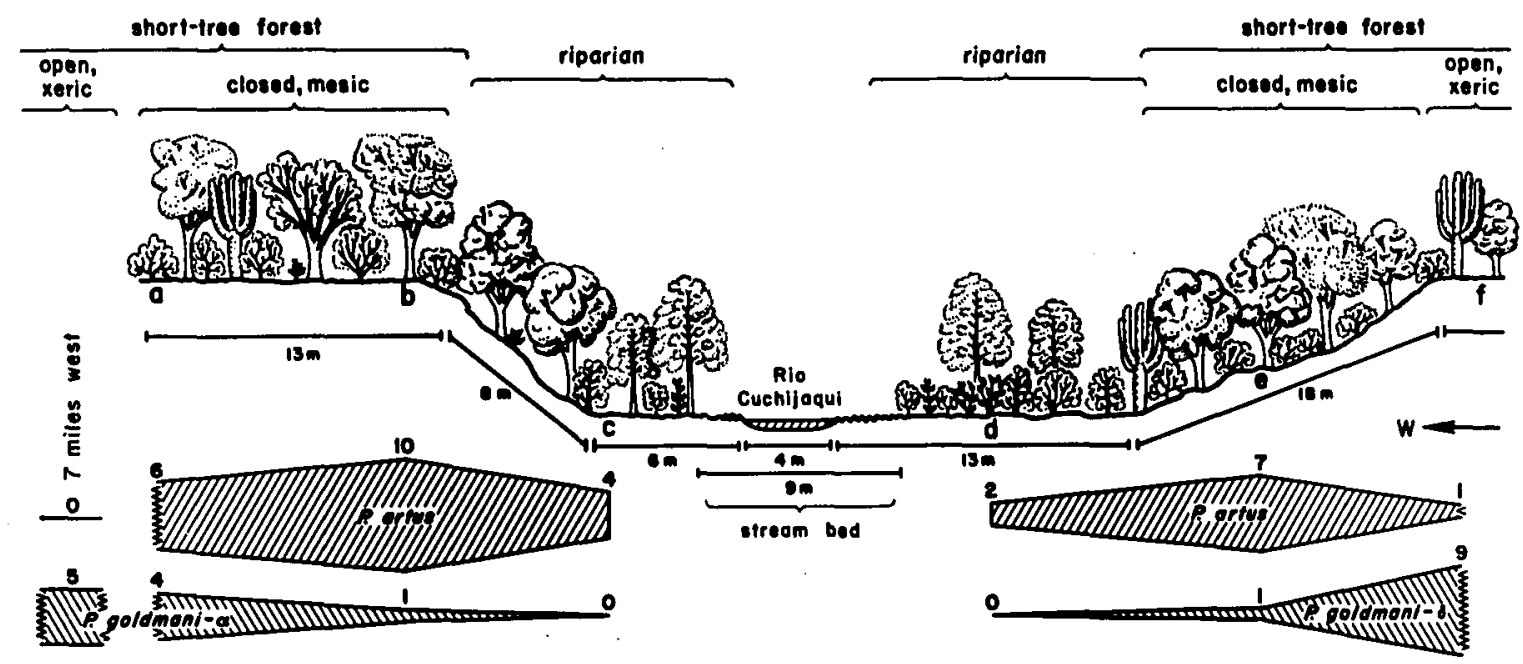

Fig. 13. Diagramatic cross-section of the Rio Cuchijaqui and adjacent area at 12 miles east of Alamos, Sonora, Mexico.

Lateral extent of major habitats is indicated, as well as the distribution and density of $\underline{P}$. goldmani and $\underline{F}$. artus within these habitats. Letters indicate trap stations ( 20 traps per station set parallel to stream), and numbers refer to the sample size of the two species trapped at each station. Records were compiled for late January and late September, 1968. 
habitats 12 miles east of Alamos at the Rio Cuchijaqui. This indicates the relative scarcity of $\underline{P}$. goldmani within the riparian community, presumably because of ecological replacement by $\underline{P}$. artus. As a consequence, therefore, the adjacent populations (and races) of $\underline{P}$. goldrnani at the locality are not only separated by approximately nine meters of stream bed, but by at least four to five times that widh. This strongly suggests that the major factor limiting dispersal across the river is the presence of $\underline{P}$. artus within the riparian and mesic short-tree forest communities, and not stricty the strean 1tself. Undoubtediy, however, such major rivers as the Rio liayo and Rio Fuerte have played (and continue to play) more definite liniting roles as o.ctual. physiographic barriers than has the smaller Rio Cuchs jaqui.

On the Rio Cuchijaqui where movement across the stream would be relatively easy, little if any dispersal apparently occurs. If the Iimitation to dispersal is imposed by competition with P. artus, by actual physiographic conditions, or both, racial dispersal is restricted and can be considered inconsequential. Each race is, therefore, maintained as a large monomorphic population circumscribed by distinct geographic boundaries. Ilttle can actualiy be stated at this time concerning the degree of gene rlow between adjacent races. It would 
appear that it is nearly nonexistent, since only three chromosomally hybrid individuals are recorded from a sample of 221 mice trapped within the contact zones. It must be concluded that, although adjacent races could exchange genes successfully, the situation is rare due to restrictions placed on sympatric contact by physiographic and ecological baxriers. 
MORPHOLOGICAI, TRENDS

Five characters based on measurements from both the cranium (occipito-nasal length, mastoid breadth, and bullar length) and whole specimen (total length and length of hind foot) were analyzed for trends in geographic veriation of external morphology within $\underline{P}$. goldmani. These parameters were selected because they were considered diagnostic for the species by Anderson (1964) and because they exhibit maximal interpopulation but minimal intrapopuletion variam tion. The data for the five neasurements were based on the examination of 291 individuals from 44 localities. The general purpose of the analysis was to determine if phenotypic variation (in terms of shifts in direction or magnitude of clines) corresponded in any significant way to the present division of the species into chromosome races.

The coastal populations tend to show more variation than those of interior regions. Four of the five characters in the former area, but only one in the latter display clinal variation. All clines are expressed in terms of greater structural size in the more southern populations. The greater variation in coastal populations is understandable since the general habitat along the coast is much more 
diversified than that of the interior. East-west clinal variation is slight, except in the south where all characters tend toward greater size in the more southeastern populations. Large samples from contact situations between adjacent races are avallable from only three general areas: (1) the vicinity of Navojoa (between races $\gamma$ and $\alpha$ ); (2) the Rio Cuchijaqui at 17.5 and 20 miles south of Alamos (between races $\alpha$ and $\delta$ ); and (3) the vicinlty of Presa 0rtiz and Presa Hidalgo near El Fuerte (between races $\alpha, \delta$, and $\beta$ ). Data from these adjacent populations are given in Tables 1 through 3.

Examination of the tables reveals no generaj. signiflcant chánges in the expression of morphological characters across the major rivers. Slight changes are seen between adjacent populations near Navojoa (i.e., 2 and 6 miles north of Navojoa and 3.5 miles east of Tesial in both total length and bullar length, but these nay be due to the srall sample sizes. On the Rio Cuchijaqui, a. significent difference between races $\alpha$ and $\delta$ is seen in the length of the hind foot, and differences are recognizable in both total length and mostoid breadth, but these axe not significant. Finally, near El Fuerte where three races, $\alpha, \delta$, and $\beta$, come together, significant differences are noted between races $\alpha$ and $\delta$ on one hand and $\beta$ on the other in bujlar length, with $\theta$ slicht but non-significent difference betireen races $\alpha$ and $\delta$ in total 
Table 1. Summary of morphologlcal characteristics of contiguous populations of races $\gamma$ and $\alpha$ in the vicinity of Navojoa, Sonora, Mexico. Means are with 95 per cent confidence intervals $\left(s_{\bar{x}} \times t_{n-1}\right)$; ranges are enclosed by parentheses; sample sizes are given for measurements in milizmeters. Males and females are combined.

\begin{tabular}{|c|c|c|c|c|}
\hline character & 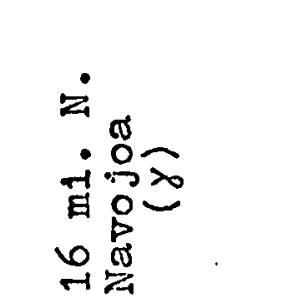 & 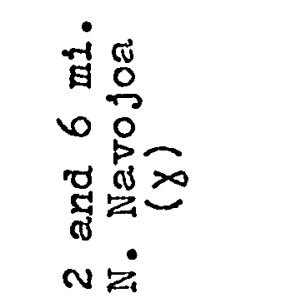 & 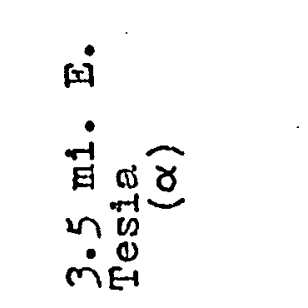 & 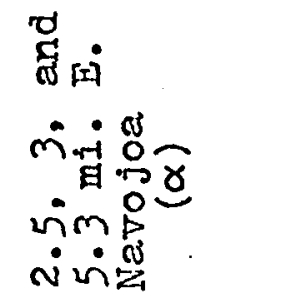 \\
\hline $\begin{array}{l}\text { total } \\
\text { length }\end{array}$ & $\begin{array}{c}182 \cdot 5 \pm 5 \cdot ? \\
(166-216) \\
N=20\end{array}$ & $\begin{array}{c}193.8 \div 6.6 \\
(184 \cdot-202) \\
N=6\end{array}$ & $\begin{array}{c}186.8 \pm 6.3 \\
(179-192) \\
N=6\end{array}$ & $\begin{array}{c}183 \cdot 4 \cdot 5 \cdot 9 \\
(170-213) \\
N=18\end{array}$ \\
\hline $\begin{array}{l}\text { length of } \\
\text { hind foot }\end{array}$ & $\begin{array}{c}24.7 \pm 0.5 \\
(23-27)^{N=23}\end{array}$ & $\begin{array}{c}25.3 \div 1 \\
(23-27)^{4} \\
N=6\end{array}$ & $\begin{array}{c}25.2 \pm 0.8 \\
(24-26)^{8} \\
N=6\end{array}$ & $\begin{array}{c}24 \cdot 5 \div 0.4 \\
(23-26)^{N}=21\end{array}$ \\
\hline $\begin{array}{l}\text { occipito. } \\
\text { nasal } \\
\text { length }\end{array}$ & $\begin{array}{c}26.62 \pm 0.41 \\
(24.9-28.2) \\
N=23\end{array}$ & $\begin{array}{c}27.03 \div 0 \cdot 38 \\
(26.3-27 \cdot 3) \\
N=6\end{array}$ & $\begin{array}{c}26.88 \pm 0.46 \\
(26.1-27.4) \\
N=6\end{array}$ & $\begin{array}{c}26.49 \pm 0.43 \\
(25.2-28.4) \\
N=21\end{array}$ \\
\hline $\begin{array}{l}\text { mastoid } \\
\text { length }\end{array}$ & $\begin{array}{c}13.60 \pm 0.18 \\
(13.0-14.9) \\
N=23\end{array}$ & $\begin{array}{c}13.68 \pm 0.22 \\
(13.3-14.0) \\
N=6\end{array}$ & $\begin{array}{c}13.78 \pm 0.36 \\
(13.2-14.1) \\
N=6\end{array}$ & $\begin{array}{c}13.66 \div 0.20 \\
(12.9-14.9) \\
N=21\end{array}$ \\
\hline $\begin{array}{l}\text { bullar } \\
\text { length }\end{array}$ & $\begin{array}{c}6.77 \pm 0.11 \\
(6.3-7.4) \\
N=23\end{array}$ & $\begin{array}{c}6.95 \pm 0.30 \\
(6.6-7.3) \\
N=6\end{array}$ & $\begin{array}{c}6.50 \pm 0.36 \\
(6.1-6 \cdot 9) \\
N=6\end{array}$ & $\begin{array}{c}6.72: 0.15 \\
(6.3-7.5) \\
N=21\end{array}$ \\
\hline
\end{tabular}


Table 2. Summary of morphologlcal characteristics of contiguous populations of races $\alpha$ and $\delta$ south of Alamos, Sonora, Nexico. See Table 1 for explanation.

\begin{tabular}{|c|c|c|}
\hline character & 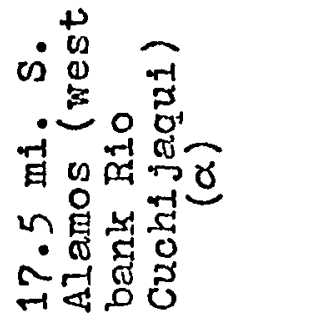 & 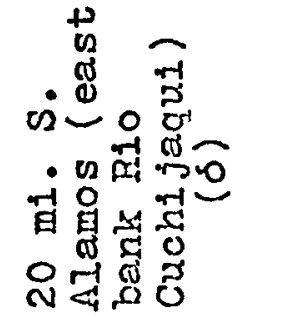 \\
\hline $\begin{array}{l}\text { total } \\
\text { length }\end{array}$ & $\begin{array}{c}194 \cdot 3 \pm 3.5 \\
(175-208) \\
N=26\end{array}$ & $\begin{array}{c}190.6 \pm 3.6 \\
(185-205) \\
N=12\end{array}$ \\
\hline $\begin{array}{l}\text { length of } \\
\text { hind foot }\end{array}$ & $\begin{array}{c}25.0 \pm 0.2 \\
(24-26)^{2} \\
N=34\end{array}$ & $\begin{array}{c}24 \cdot 4 \pm 0.3 \\
(24-25) \\
N=18\end{array}$ \\
\hline $\begin{array}{l}\text { occipito- } \\
\text { nasal } \\
\text { length }\end{array}$ & $\begin{array}{c}26.4 .5 \pm 0.25 \\
(25.0-27.7) \\
N=32\end{array}$ & $\begin{array}{c}26.30 \pm 0.32 \\
(25.2-27 \cdot 4) \\
N=18\end{array}$ \\
\hline $\begin{array}{l}\text { mastold } \\
\text { length }\end{array}$ & $\begin{array}{c}13.63 \pm 0.12 \\
(12.9-14.2) \\
N=32\end{array}$ & $\begin{array}{c}13.45 \pm 0.13 \\
(13.0-13.9) \\
N=18\end{array}$ \\
\hline $\begin{array}{l}\text { bullar } \\
\text { length }\end{array}$ & $\begin{array}{c}6.80 \pm 0.11 \\
(6.3-7.1) \\
N=32\end{array}$ & $\begin{array}{c}6.74 \pm 0.11 \\
(6.4-7.1) \\
N=18\end{array}$ \\
\hline
\end{tabular}


Table 3. Summary of morphological characteristics of contiguous populations of races $\alpha, \delta$, and $\beta$ in the vicinity of El Fuerte, Sinaloa, Mexico. See Table 1 for explanation.

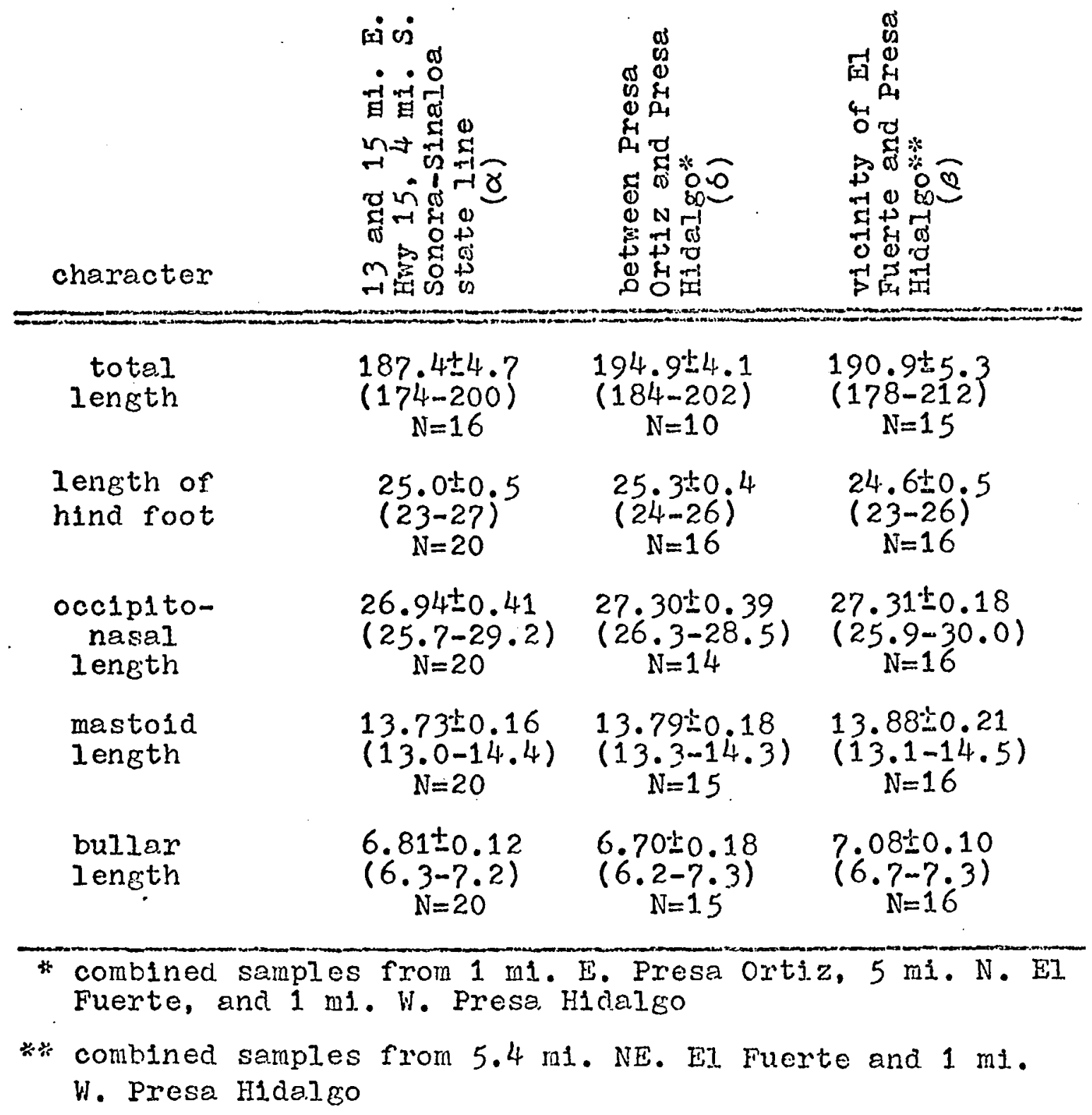


length. Other characters elther demonstrate no difference, or slight clinal variation. In general, there is no correspondence between chromosomal change and morphological change.

The analysis of morphological features emphasizes tro major factors. First, holomorphology is a different level of organization than the chromosomal level, and, as such, changes in either will not necessarily be correlative. Secondly, the expression of the phenotype is more strongly dependent on ecological factors than on gross chromosomal axrangements. The first point is best 1Ilustrated in studies of the chromosomal variants of the European shrew, Sorex araneus, where members of Type $A$ and Type $B$ are morphologically inds singuishable, but are ecologically distinct and behave as biological species (Meylan 1964 , ott 1968). The second point is understandable since differences in chromosomal complenents between individuals or races will ordinarily afrect directly only the fecundity and viability of hybrid off spring, not their phenotypes. 


\section{DISCUSSION}

Both inter- and intrapopulation variation in chromosome complement have been described for a variety of mamalian species. A majority of these involve Robertsonian transformations (Matthey 1966a, b, c; Meylan 1964, 1965, 1967; Nadler 1964), but several systems have been described where presuned reciprocal translocations and pericentric inversions axe predoninant (Natthey 1966d, Shellhammer 1967, patton and Dingman 1968). Most examples fitting either of the two categories involve the present arrangernent of allopatric chromosome races, where each race is monomorphic (j.e., one homozygous for the original arrangement and the other for the derived condition), and where no populations with individuals of intermediate condition (i.e., heterozygous) are knom. Although within P. Eoldmeni a few (3) Individuals from contact localjties are known which are chromosomaljy intermediate between adjacent races, each race can be considered monomorphic and allopatric. Known physiographic and/or ecological barriers maintain contiguous allopatry of the races. Consequently, P. goldmani conforms to the standard clrcumstance of other species with allopatric chromosone races. 
Chromosome and population deta indicating allopatric conditions are obviously not compatible with a system of balanced or even transitional polymorphism within the specles. Therefore, sone authors (e.g.. Nadler 1964) have considered the occurrence of monomorphic chromosome races as on intermediate evolutionary stage between a single population characterized by a balanced polymorphic system and that of two reproductively isolated (allopatric or syrnatric) species with difrerent karyotypes (e.g., Matthey 1964a, b, 1965a). The general concept is that upon division of an ancestral polymorphic population, heterozygotes are selected against and eliminated, leaving chromosomally distinct populations. It 1s, however, not necessarily true that initial stable polymorphisms be sources of new, specific nonomorphisms. In numerous cases it is clear that stable polymorphism does not lead to monomorphisms In txansit (Lewis and John 1963; John and Lewis 1966). Moreover, White (1965) has strongly defended the position that there is no need to pass through a stage of balanced polymorphism to arrive at allopatric or parapatxic mono.morphic chromosome races.

This point is of particular interest in interpreting the histoxical events and population dynanics which led to the formation and present distribution of chromosome races in $\underset{p}{p}$. goldmans. For example, it is difficult to concejve of 
an Initially large, continuous population polymorphic for four centric fusions and two pericentric invexsions. Even more difficult to concelve is a force great enough to split the primitive population into six allopatric ones, and then. to permit selection of the proper homozygote in each to produce the current correspondence in both geography and phylogeny of the races. A much more logical intexpretation is that of White (1965) which is not based on an ancestral widespread condition of balanced polymorphism, or even such a system at each level in the phylogeny corresponding to each new chromosomal transformation.

If these arguments are applied to the evolution of P. Goldmani, two basic and different models can be proposed as mechanisms allowing for chromosomal change: a stasipatric and an allopatric model.

The stasipatric model of White et al. (1967) and White (1968) was proposed Initially to explain the apparent direct conversion of an essentially continuous population of morabine grasshoppers into a number of parapatric chromosome races. This is a very similar situation to the present contiguous races in P. goldinan1. The inherent difficulties with the model have been discussed at length by Key (1968), and need not be covered in such detail here. The basic probleins are two fold. First, strict allopatric interpre. tations can be applied to White's data and hence formulation 
of a new model (stasipatry) is not necessitated. Second, only the peripheral model (White 1968: 1068, Fig. 2C), wherein new chromosome arrangements become established by chance in small, isolated colonies, is possible for species, such as P. goldmani. not characterized by low vagility and highly speciallzed ecological requirements. Therefore, the only real difference between a stasipatric model and an allopatric one, as applied to $\underline{P}$. goldmanl. is that in the former the new arrangement spreads inward through the exist-Ing species range displacing the original arrangenent, not outward into previously unoccupied territory.

There are, nevertheless, several difficulties j.n the application of the restricted stasipatric interpretation to the present problem. First, the nodel requires that each new chromosome axrangement move into the interior of the species range, displacing the old. However, there is evidence that the geographic and ecologic position of at least Race- $\theta$ represents a distal expansion of the total range of P. goldmans, not an encroachinent on that of 1 ts parent, Race- $\epsilon$. The habitat occupled by Race- $\theta$ j.s unique for the species, and therefore would seem to represent one that was invaded rather than one in which the spec1es has alvays been present.

Second, tension zones betreen adjacent races, a basic tenet of White's model, are not found in the present 
case, unless the rivers separating the four southern races are considered convenient barriers to a continual tension zone.

Third, it seems dificult to rationalize under the stasipatric model that each new arrangement provides for greater adaptation to an already stable environinent. If, indeed, the environment vere not stable, but continuousiy changing, the model would not take into consideration the effects on the distribution of P. goldimani by extraspecific ecological factors, such as competitive species. Therefore, the stasipatric nodel really considers only the intraspecific genetic relationships, and neglects ecological conditions which would be expected to exext pressures on the species. Ecological conditions, in combination with the internal genetic systems of the species, is a more realistic mechanism for both causing and allowing chromosomal change. In my opinion this approach is satisfied by an allopatric concept, not by a stasipatric one.

Under the aljopatric interpretation, one must consider a disjunction in the ancestral population to allow for the formation and consequent relnvasion of new chromosomal iypes into the present center of the species range. Race- $\theta$ could be derived without necessiteting an original disjunction by budding from Race- $\epsilon$ at the north. eastorn periphery, but races $\gamma, \alpha$, and $\delta$ could not (consult 
Fig. 1). The latter races, located in the interior of the species range, could have occupied these areas under an allopatric schene only if the central area were once devold. or nearly so, of the species due to disjunction of the ancestral population. The crux of the allopatric model is, therefore, evidence for such an initial disjunction. Any mechanism for the disjunction of an ancestral population of $\underline{P}$. goldmani necessarily involves spatial changes of biotic communities. For a coriplete displacement of the species within the area, one must assume climatic vicissitudes of sufficient magnitude to displace oak woodland communtties from the Sierra Madre occidental to the coost, a downward vertical shift of more than 600 meters and a westward horizontal shift of some 110 kilometers. Although there is some evidence to indicate shifts in floral and faunal distributions in the area of the Sonoran Desert because of climatic changes of the Late Pleistocene (Martin 1963; Nartin and Mehringer 1965), data is presently not available to even suggest the impact of pluvial conditions on the phytogeography of the region in question, much less to consider vegetation changes of the required magnitude. Moreover, zoogeographic data (Burt 1938) do not indicate the presence of najor faunal breals through the region, as may be expected with such drastic climatic and vegetation changes. 
An alternative solution involving less dramatic climatic changes appears more feasible, for although vegem tation shifts are still necessiteted, they would be of a reasonably low magnitude. This alternative visualizes a spatial spreading of the chromosomal variants of $\underline{P}$. goldmani in response to both vegetation (cormunity) changes and interspecific competition pressures. The major force creating the split in the original P. goldineni population would be competition by the sibling species, $\underline{\text { p. artus. }}$ which even now actively restricts dispersal of $\underline{P}$. goldmani. The changes in disixibution of both species with the concomitant formation of chromosome races in $\underline{P}$. goldmans is illustrated in Fig. 14.

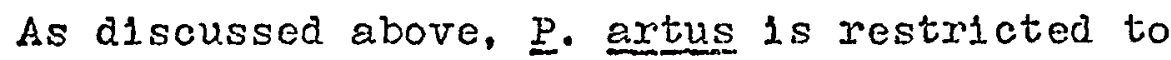
mesic riparian and rully-developed short-tree forest communities in areas of contact with $\underline{P}$. goldmani. Under these circumstances, climatic changes during the Late Pleistocene need only be great enough to allow westrard expansion of the rich tropical deciduous forest, from its present position close to the base of the siexra Madres, toward the coast between the lower Rio Yaqui and Rio Fuerte river valleys. An accompanying expansion of riparian comrunities along the major river courses would also occur. As a consequence, the present ecological position of $P$.

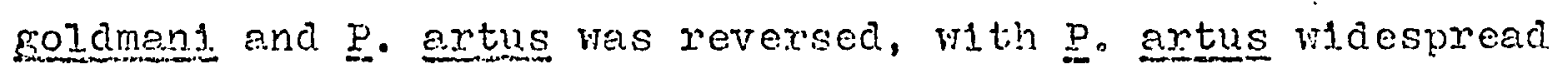


Fig. 14. Allopatric interpretation for the origin of the chromosome races of $P$. goldman1.

(A) Distribution of $\mathrm{P}$. goldmeni and $\mathrm{P}$. ertus during pre-pluvial period (early Wisconsin); (B and C) distributional changes during full pluvial; ( $D$ and $E$ ) postpluvial changes leading to the present (F) distributions of the species. Map $A$ is based on the present ranges (F) of the species as mapped by Anderson (1964). 


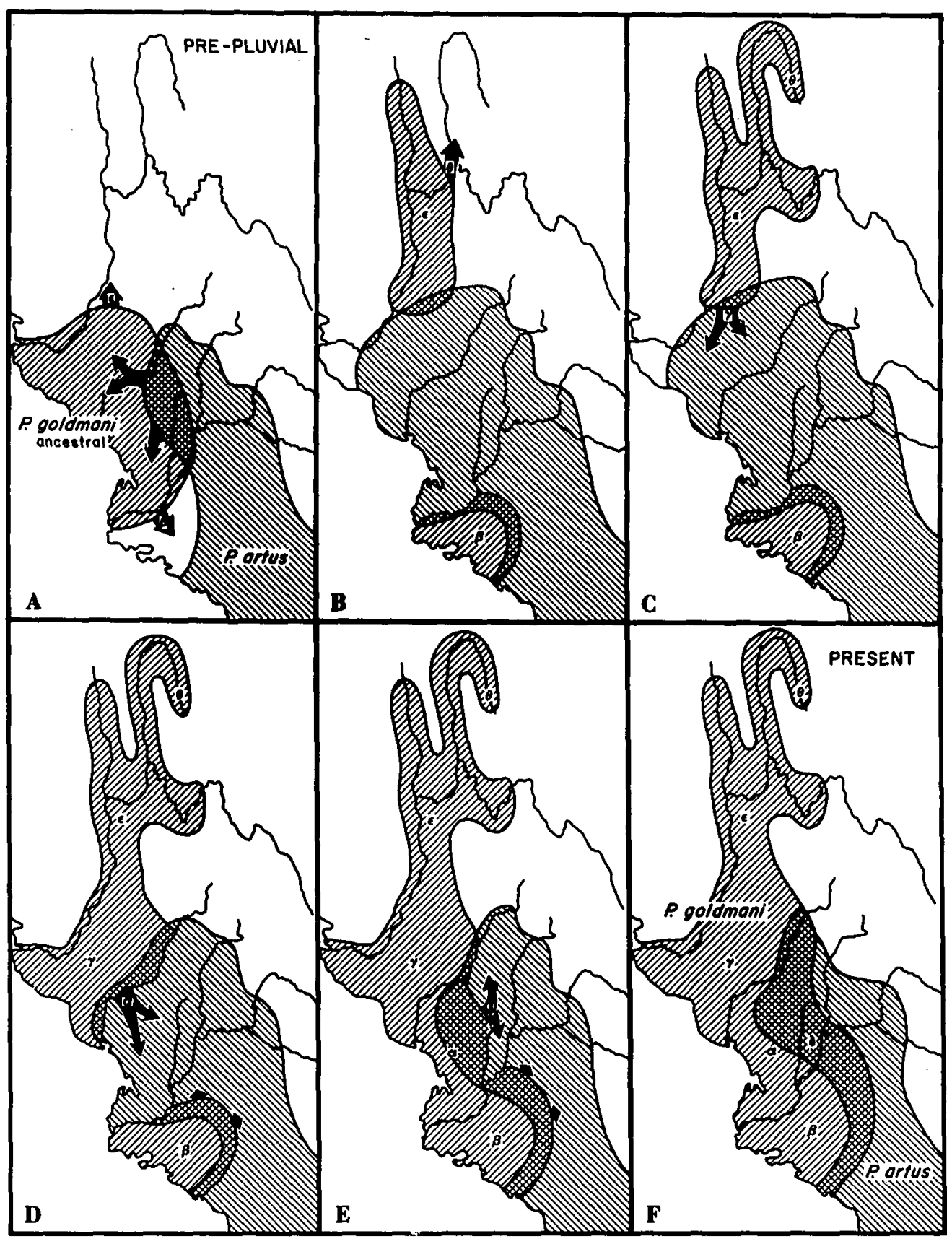

Fig. 14. Nllopatric interpretation for the origin of the chromosome races of $\underline{P}$. goldmani. 
throughout the area and $p$. Boldmani limited to highly disjunct, small populations restricted to the more arid habitats along the coast. Indeed, examination of the present range of 2 . axtus (Fig. 14F) shows that the species need only extend its range a few miles westward rrom the vicinity of Navojoa, Sonora, to effectively divide the range of $\underline{p}$. goldmani. The range of $\underline{p}$. artus may even have extended farther to the west just a few decades ago, prior to the destruction of its riparian habjtat along the lowex Pío Mayo by man.

The initial ancestral distribution for $\underline{P}$. artus and P. goldmani (Fig. 14A) can be interpreted from the present geographic relationships of the two species. Westward expansion of $P$. extus during a time of increasingly moist conditions foxcad the retreat of $\underline{P}$. golomens into two essentially disjunct populations: to the north into the middle Rlo Yaqui valley and to the south into northwestern Sinaloa along the coast. The chrorosome arrangeinents presently represented by races $\beta$ and $\epsilon$ thus arose by budding froin the ancestral population as the species shifted its range because of competition by $\underline{p}$. axtus during a period of climatic and accoinpanying regetation changes. The end result was the elimination of the ancestral kexyotype. Race. $\theta$ probably arose from race.e at a time when the majo: vegetation asscirbleges of the mialie and uppe: 
Rio Yaqui drainage had a more subtropical thornscrub aspect (i.e., at the height of the Wisconsin Glacian Stage, or corresponding pluvial perlod). The present distribution of Race- $\theta$ in the lower montane woodland and riparian habitats of the upper Rio Bavispe indicates a more recent restriction c of the ecological range of the species (and race) since the Pleistocene. This is compatible with the proposed changes toward more xerlc conditions in the area at the end of the pluvial period (Martin 1963).

The return of more arid conditions to the area of northrestern Mexico gradually revisea the direction of plant community change initiated at the beginning of pluvial times, and hence the ecological position of $\underline{P}$. axtus and P. goldmani. The former, more mesic adapted species, was forced to retreat into narrowing riparian communities and restricted full short-tree forest in an eastward as well as southeastward direction. Reinvasion by P. goldmand (Figs. 13C, D, and $E$ ) was possible only frorn the north (Race-c or a derivative). Dispersal noxthrard from the south by Race- $\beta$ was halted by the Rio-Fuerte (by far the largest of the rivers actine as physiographic barriers), and also because $\underline{p}$. artus was retreating against Race- $\beta$ from the north. In other words, the last areas to be vacated by p. artus were those on the north bank of the Rio Fuerte, and even today the species is very abundant in the eastem end of the kio Fueste valyey within the present ranges of 
races $\delta$ and $\beta$. Southern expansion of P. goldmani was presumably in waves, as each of the westward flowing rivers afforded at least temporary barriers to continuous movement. The proposed chronological vegetation and consequent population changes within P. Boldmani (both in direction and extent) are based on the pattern of phylogeny and present distribution of the chromosome races. As the species reinvaded the area between the lower Fio Yaqui and the Rio Fuerte, new chromosomal arrangements axose and became widespread betrie the geographic limits provided by the major rivers. That is, Race- $\gamma$ arose from Race-. $\epsilon$ and invaded the area between the lover Rio Yoqui and the Rio Mayo; Race- $\alpha$ was derived from Race- $\gamma$ and occupied the coast from the Rio Mayo south to the R10 Fuerte and east as far as the R10 Cuchijaqui; and finally, Race- $\delta$ arose from Race- $\alpha$ and Invaded the last widespread refuge of $\underline{p}$. artus, the area between the Rio Cuchljaqui and the Rio Fuerte. One is tempted to say that the new chromosomal arrangements were necessary to enable reinvasion of the species into the area. Unfortunately, one can, at the moment, only speculate on the adaptive significance of the different chromosome combinations and of theix possible role in phylogenetic divergence. In some instances, rearrangements have been shown to alter chiasra frequency as vell as recombination, thereby exexting a dixect genetsc effect on evolution 
(White 1968). In other examples, however, such rearrangements apparently have had minimal effect and only serve as a morphological maxker indicative of the direction taken by evolution.

Homozygous chromosomal differences between populations of the same species indicate that each new population began with a few individuals and that the new genetic combination was favored by selection (Hallace 1959). selection expressed in texms of fast and close inbreeding would lead rapidly to homozygous denes, if homozygosity were necessary to maintain the nev genetic integrity of the population (Carson 1965a). Such significant genetic changes (both the initial formation of a new arrangernent, and its subsequent fixation) would occur most readily in small, peripheral populations (Carson 1959, 1965b; Wright 1960).

The presence of rivers 8.5 both physlographic and ecologic barriers presurably played the same significant role in the past as today. They allowed the fixation of a constellation of genes (or new chromosomal arrangenents) sultable to meet the selective demands on the small, peripheral populations of $\underline{P}$. goldmant on one side of a river. Horeover, they enabled rnaintenance of the selected combinations so that their efficiency would not be impaired by continual recoribination vith genes (or errangenents) 
entering the population from the other side of the river. Each new chromosomal reaxrangement, providing for reduced recombination, could therefore allow the further spread of the species range as long as the disruptive migration from the other populations was held at a minimum. As already noted, the predominant mechandsm of chromosomal change in $P$. goldrani is centric fusions. Such a mechanism cannot itself serve as an effective chromosomal isolating barrier between adjacent races since a fusion heterozygote produces only balanced gametes and will, therefore, suffer no loss of viability or fertility. The presence of rivers have alded not only the formation of new chromosomal combinations, but also the initia. selection and continued maintenance of the enetic integrity of each new race as it became established. Possibly it was this genetic integrity which pexmitted the expansion of $\underline{P}$. Boldmanj. during a period of habitat changes and in the face of progressively stronger competjtion by P. artus.

Interpretation of the origin and spread of the chromosomal variants of $\underline{P}$. goldmant in response to vegetation changes and competition pressures axe certalniy in accord with the theoretical grounds established by Wright and exemplified by Mayr (1963), Carson (1965a), and others. 


\section{SPECIMENS EXAMINED}

Localities are listed separately for each race of P. goldmant, first by state, and then by geographic position within each state from north to south. Localities for races $\alpha, \beta, \gamma$, and $\delta$, as 11sted, are mapped separately in Figs. 4 and 5; no individual localities for races $\epsilon$ and $\theta$ are mapped. Numbers prerixed by UA represent specimens (skin and skull or skeletion only) deposited in the collection of manmals, Department of Biolojicel. Sciences, The University of Arizona, Tucson. Numbers prefixed by JLP represent specimens (skin and skull, skeleton only, or fluid preserved) numbered in the author's personal field catalogue.

\section{Perognathus goldmani- $\alpha$}

Total, 174. Sonora: $3.5 \mathrm{mi}$ E Tesia (UA 16804...09; JLP 854-57); Rio Mayo, Navojoa (UA 15200); 2.5 mi E Navojoa (UA 15614-25, UAI5910); $3 \mathrm{ml}$ E Navojoa (UA 15194-96); 5.3 mi E Navojoa (UA 15210-12, UA 15626-27); $10.2 \mathrm{mi}$ E Navojoa (UA 15176-77); south banik Rio Mayo at Presa Mocuzari (JLP 1692-95); $11.2 \mathrm{mi} \mathrm{W}$ Alomos (UA 11607); $11.5 \mathrm{mi}$ W Alamos (UA 11509, UA 12972, UA 12991); $7.0 \mathrm{mi} \mathrm{V} \mathrm{Al.amos} \mathrm{(U \Lambda} \mathrm{J.1508,}$ UA 12962.63); $5.0 \mathrm{mi}$ W Alamos (UA 10536-40, UA 10846, UA 11502, UA 11552-54, UA 11599, UA 10604-05, UA 12993); 5.2 
m1 E Alamos (UA 11600, UA 11606, UA 12974...75, UA 12992); west bank Rio Cuchijaqui, $12 \mathrm{mi}$ E Alamos (JLP 1035, JLP 1615. JLP 1717-1719); Rio Cuchijaqui, $8 \mathrm{mi} s$ Alamos (UA 14112); $17.5 \mathrm{mi}$ S Alamos, west bank Rio Cuchijaqui (JLP 1634-40, JLP 1642-69); base of Cerro Hasiaca, 1.5 m1 N Masiaca on Hwy 25 (UA 15629-30). Sinaloa: $4 \mathrm{ml}$ S SonoraSinaloa state line on HWy 15, $8 \mathrm{ml}$ E (UA 16810, JLP 860869. JLP 871); 4 mi S Sonora-Sinaloa state line on Hwy 15. $13 \mathrm{ml}$ E (UA 16811-12, JLP 872-885, JLP 889--890): $4 \mathrm{mi} \mathrm{s}$ Sonora-Sinaloa state line on Liwy $15,15 \mathrm{mi}$ E (UA 1681321); $10 \mathrm{mi} \mathrm{S}$ Tapizuelos (Sonora) (JLP 977); $15 \mathrm{mi} \mathrm{S}$ Tapizuelos (Sonora) (JLP 978-m989); noxth bank Rio Fuerte at Hwy 15 (JL,P 1016-20).

\section{Perognathus goldmani $-\beta$}

Total, 36. Sinaloa: Rio Choix, $3 \mathrm{~km} \mathrm{NE}$ Choix. (JLP. 998-1004, JLP 1006-07); south bank Rio Fuerte, ca 1 mi W Presa Miguel Hidalgo (JLP $992 \mathrm{~m} 94$ ); $5.4 \mathrm{ml}$ NE EI Fuerte (UA 12952-58, UA 12968-71, UA 15931, JLP 1090); $21.9 \mathrm{mI} \mathrm{NE}$ San Blas (UA 12973); $11.8 \mathrm{mi}$ NE San Bla.s (UA 22959-60; UA 12966-67); $3 \mathrm{mi} \mathrm{E}$ Verdura (UA 13442, UA 11555. UA 11601-03).

\section{Perognathus golcmeni- $\gamma$}

Total, 44. Sonora: Presa Alvaro Obregon (UA I 4403. UA 15190--92); $16 \mathrm{mi} \mathrm{N}$ Navojoa on Ewy 15 (UA 15591-98, UA 15600-08; UA 15613, UA 15901., UA 15911-15); 6 Inj. N Navojoa 
on Hwy 15 (UA 15609-12, UA 15903); $2 \mathrm{mi} \mathrm{N}$ Navojoa on Hwy 15 (UA 15909); north bank Rio hayo at Presa Mocuzar1 (JLP 16961704); $6 \mathrm{mi}$ SE Tepahui (JIP 1027).

\section{Perognathus goldmani- $\delta$}

Total, 53. Sonora: south bank Rio Mayo at Las Panelas (JLP 1040-1045); east bank Rio Cuchl jaqui, $12 \mathrm{ml} \mathrm{E}$ Alamos (JLP 1030, JLP 1033, JIP 1631, JLP 1633, JLP 1623, JLP 1625, JLP 1628, JLP 1720-22); east bank Rio Cuchijaqui, $20 \mathrm{ml} \mathrm{S}$ Alamos (JLP 1670..73, JLP 1675-91). Sinaloa: $1 \mathrm{ml}$ E Presa Josepfa Oritz (JP 1705-09, JLP 1711, JLP 1713-16); 5 mi N El Fuerte (UA 15173-75, UA 15631); north bank Rio Fuerte, ca 1 mi W Presa Miguel Hidalgo (JuP 990-91).

Perognathuis goldmani $\alpha$ x $\delta$ hybrids

Total, 3. Sonora: east bank Rio Cuchijaqui, $20 \mathrm{mi}$ S Alamos (JLP 1674). Sinaloa: I ml E Presa Josepra Ortiz (JLP 1710, JLP 1712).

\section{Perognathus goldinand- $\epsilon$}

Total, 7. Sonora: 2 mi E Moctezuma (JLP 910, JLP 912); $3.5 \mathrm{ml} \mathrm{S}$ Moctezuma (UA 16822); $4.5 \mathrm{mi}$ S Noctezuma (UA 15181-82); 1 mi S TOnichi (UA 15632-33).

\section{Perognathus goldneni- $\theta$}

Total, 2. Sonora: 1 m 1 Aribabi (UA 15908); 1 mi N Huachinere (UA 15907). 


\section{IITERATURE CITED}

Anderson, S. 1964. The systernatic status of Perognathus axtus and Perognathus goldmani (Rodentia). Aner. Mus. Nov., 2184: 1-27.

Bender, M. A. and E. H. Y. Chu. 1963. The chromosomes of primetes. Pp. 261-311, in Evolutionary and Genetic Biology of Primates, Vol. 1 (J. Buettner-Janusch, ed.). Academic Press, New York.

Burt, H. H. 1938. Faunal relationships and geographic distribution of marrmals in Sonora, Mexico. Univ. Mich. Mus. Zool. Misc. Publ., 39: 1-77.

Carson, H. L. 2959. Genetic conditjons which promote ox retard the formation of species. Gold Spring Harb. Symp. Quant. Biol., 24: 87-105.

1965a. Inbreeding and cene fixation in small populations. Pp. 281-308, in Heritage from Mendel (R. A. Brink, ed.). The Univ. Wisc. Press, Madison.

- 1965b. Chromosomal polymorphisis in the H1despread species of Drosophi1a. Pp. 503-531, in The Genetics of Colonizing Species (H. G. Baker and G. L. Stebbins, eds.). Academic Press, New York.

Findley, J. S. 1967. A black population of the Goldman pocket mouse. Southwestern Nat., 12: 191-192.

Gentry, H. S. 1.942. Rio Mayo Plents. A study of the flora and vegetation of the valley of the Rio Mayo, Sonora. Carnegie Inst. Wash., Publ. 527: 1-316.

Hall, E. R. and K. R. Kelson. 1959. The Mamrnals of North Amerlca, Vol. 1. Ronald Press Co.. New York. $649 \mathrm{p}$.

John, B. and K. R. Lewis. 1966. Chromosome variability and geographic distribution in insects. Science, 152: $711-721$.

Key, K. H. I. 1968. The concept of stasipatric speciation. Syst. Zool.,: 17: 14-22. 
Leopold, A. S. 1950. Vegetation zones of ifexico. Ecology, 31: $507-518$.

Levan, A., T. C. Hsu, and H. F. Stich. 1962. The 1deogram of the mouse (Mus musculus). Hereditas, 48: 677-688.

Lewis, K. R. and B. John. 1963. Spontaneous interchange in Choxthippus brunneus. Chromosoma, 14: 618-637.

Martin, P. S. 1963. The Last 10,000 Years. Univ. Ariz. Press, Tucson. $87 \mathrm{p}$.

Martin, P. S. and P. J. Mehringer, Jr. 1965. Pleistocene pollen analysis and blogeography of the Southwest. Pp. 433-451, in The Quarternary of the United States (H. E. Wright and D. G. Frey, eds.). Princeton Univ. Press, New Jersey.

Matthey, R. 1964a. Evolution chromosomique et speciation chez les Mus du sous-genre Legeada Gray 1837. Exper1entia, 20: 657-665.

- 1964b. La signification des mutations chromosomiques dans les processus de speciation. Etude cytogenetique du sous-genre Lesgada Gray (Mammalla-luridae). Arch. Blol., 75: 169-206.

1965. Cytogenet1que des Mus africains du sous-genre Leggada. Etude de 35 exemplaires provenant de l'afrique de Sud, de la Cote d'Ivoire et du Gabon. Caryologia, 18: 161-179.

- 1966a. Evolution chromosomique et speciation chez des souris africalnes du sous-genre Leggada (Gray, 1837). Ann. Mus. Roy. Afr. Centr., series 8, Z001.. 144: $155-157$.

- 1966b. Cytogenetic mechanisms and speciation of mammals. Amer. Tissue Culture Assoc., Meeting of Mian1, pp. 1-11.

1966c. Le polymorph1sme chromosomique des Mus arricaines du sous-genre iegrada. Revision generaile portant sur I'analyse de 213 individus. Rev. Suisse Z0ol., 73: 585-607. 
- 1966d. Une inversion pericentrique a l'origine d'un polymorphisme chromosomique non-Robertsonian dans une population de liastomys (Rodentia-Muridae). Chromosoma, 18: 188 200.

Mayr, E. 1963. Aninal Species and Evolution. Harvard Univ. Press, Cambridge. $797 \mathrm{p}$.

Meylan, A. 1964. Le polymorphisme chromosowique de Sorex araneus L. (Mamin.-Insectivora). Rev. Suisse ZooI., 71: $903-983$.

1965. Repartition geographique des races chromosornique de Sorex araneus L. en Europe (lianm.Insectivora). Rev. Süisse Zool., 72: 636-64.6.

1967. Formules chromosomiques et polymorphisme Hobertsonien chez Blarina brevicauca (Say) (Mammalia: Insectivoral. Canad. Jour. Zool., 45: 1119-1127.

Nadler, C. F. 1964. Chromosomes and evolution of the ground squirrel, Sperrnophilus rjchardsoni. Chromosoma, 15: $289-299$.

Osgood, W. H. 1900. Revision of the pocket mice of the genus perognathus. N. Amer. Fauna, 18: 1-65.

Ott, J. 1968. Nachweis naturlj.chex repsoduktiver isolation zw1schen sorex remejlus sp. $n$. und soxex araneus

Linnaeus 1758 in de Schreiz. Rev. Suisse Z001.. 75: 53-75.

Patterson, J. T. and W. S. Stone. 1952. Evolution in the genus Drosophila. Macmillan, New York.

Patton, J. I. 1967a. Chromosome studies of certain pocket mice, eenus perognathus (Rodentia: Heterornyidae). Jour. Mamm., $48: 27-37$.

- 1967b. Chromosomes and evolutionary txendis in the pocket mouse subgenus Perompathus (Rodentia: Feteromy1dae). Southwestern Nat., 12: $429-4.38$.

Patton, J. L. and R. E. Dingman. 1968. Chromosome studies of pocket gophers, genus thoinonys. I. The specifjc status of Thononys unbrinus (Rjcharcison) in Arizone. Jour. Mamm., 49: 1-13. 
Shellhammer, H. S. 1967. Cytotaxonomic studies of the harvest mice of the San Francisco Bay resion. Jour. Mamm., 48: 549-556.

Shreve, F. and I. J. Wigeins. 1964. Vegetation and Flora of the Sonoran Desert, Vol. 1. Stanford Univ. Press, Palo Alto. $840 \mathrm{p}$.

Wahrman. J. and P. O'Brien. 1956. Nuclear content of DNA in chromosomal polymorphism in the genus Ameles (Orthoptera: Mantoidea). Joux. Morph., 99: 259-270.

Wallace, B. 1959. Influence of genetic systems on geographic distribution. Cold Spring Harb. Symp. Quant, Biol., 24: 193-204.

White, M. J. D. 1957. Cytosenetics of the grasshopper Moraba scurra. I. Meiosis of interracial and inter.. poputation hybrids. Aust. Joux. Zool., 5: 285-304.

- 1965. Principles of karyotype evolution in animais. Pp. 391-397, In Genetics Today, Vol. 2 (S. J. Geerts, ed.). Pergamon Press, Edinbuxgh/London.

1968. Models of speciation. Science, 159:
1065-ior0.

White, M. J. D., R. E. Blackith, R. M. Blackith, and J. Cheney. 1967. Cytogenetics of the viatica group of morabine grasshoppers. I. The "coastai"i species. Aust. Jour. Zool., 15: 263-302.

Wright, J. W. 1967. A new uniparental whiptail jizard (cenus Cnemidophorus) frorn Sonora, Mexico. Ariz. Acad. Sc1. 4: 185-193.

Wright, S. 1960. Physiological genetics, ecology of populations, and natura? selection. Pp. $429-475$. in The Evolution of life, Vol. 1. (Sol Tax, ed.). Univ. Chicago Press, Chicago.

Wurster, D. H. and K. Benirschke. 1968. Comparative cytogenetic studies in the order Carnivora. Chromom soma, 24 : $336 \mathrm{~m} 382$. 